\title{
Macroparasites and their communities of the European eel Anguilla anguilla (Linnaeus) in the Czech Republic
}

\author{
František Moravec and Tomáš Scholz
}

Institute of Parasitology, Biology Centre of the Czech Academy of Sciences, České Budějovice, Czech Republic

\begin{abstract}
This paper summarises the results of parasitological examinations of the European eel Anguilla anguilla (Linnaeus) in the Czech Republic, carried out at the Institute of Parasitology, Czech Academy of Sciences (previously the Czechoslovak Academy of Sciences) within the period of 50 years (1958-2008). Even though this survey is limited to the Czech Republic, it provides extensive data probably incomparable with any other study anywhere regarding the number of eels examined and parasites found. A total of 723 eels was examined from 42 localities that belong to all of the three main river drainage systems in the country, i.e. the Elbe, Danube and Oder river basins. Of the 31 species of adult and larval macroparasites including Monogenea (4 species), Trematoda (3), Cestoda (3), Nematoda (11), Acanthocephala (5), Hirudinea (1), Bivalvia (1), Copepoda (1), Branchiura (1) and Acariformes (1), most of them (30) were recorded from the Elbe River basin. These parasites can be divided into three main groups regarding their host specificity: parasites specific for eels (26\%), non-specific adult parasites occurring also in other fishes $(61 \%)$ and non-specific larvae (13\%). The highest number (19) of parasite species was recorded in the Mácha Lake fishpond system in northern Bohemia. The parasite communities in eels from the individual localities exhibited large differences in their species composition and diversity depending on local ecological conditions. The parasite fauna of A. anguilla in the Czech Republic is compared with that in other European countries. The nematode Cucullanus egyptae Abdel-Ghaffar, Bashtar, Abdel-Gaber, Morsy, Mehlhorn, Al Quraishy et Mohammed, 2014 is designated as a species inquirenda.
\end{abstract}

Keywords: parasite fauna, fish, host specificity, species diversity, Elbe River basin, Danube River basin, Oder River basin, Central Europe

Until the exotic, highly pathogenic swimbladder nematode Anguillicoloides crassus (Kuwahara, Niimi et Itagaki, 1974) was introduced into European populations of eels Anguilla anguilla (Linnaeus) in the early 1980's, there were few helminthological studies on this species of fish anywhere in the wide freshwater range, irrespective of the considerable value of the European eel fishery (Lacey et al. 1982). Since A. crassus, an agent of anguillicoloidosis, has seriously endangered both eel cultures and natural eel populations in Europe, this parasite has been intensively studied by European researchers. Along with the problem of anguillicoloidosis, an increased interest to study the parasite fauna of eels as a whole has also been evident in some European countries within recent decades (e.g. Køie 1988, Schabuss et al. 1997, Kennedy et al. 1998, Borgsteede et al. 1999, Kennedy 2001, Sures and Streit 2001, Outeiral et al. 2002, Pilecka-Rapacz and Sobecka 2004, Saraiva et al. 2005, Kristmundsson and Helgason 2007).

In the Czech Republic (a part of former Czechoslovakia), where eel is a valuable fish for pond breeding and angling, data on its parasite fauna are scarce, mostly published in faunistic and taxonomic papers (e.g. Frič 1873, 1908, John 1877, Šrámek 1901, Lucký 1953, Volf and Smíšek 1955, Dyk and Lucký 1956, 1957, 1963, Vojtková 1959, Ergens 1961, Dyk 1964, Moravec 1966, 1971, 1978, 1979a, 1992, 2001, Ergens and Lom 1970, Pár 1980, Moravec and Køie 1987, Scholz and Kepr 1988, Scholz 1989, Gelnar et al. 1990, Moravec and Scholz 1991a, Baruš et al. 1996, 1999, Škoríková et al. 1996, Moravec et al. 1997, Scholz et al. 1997, Tenora et al. 1999, Kodedová et al. 2000, Koubková and Baruš 2000) or in papers dealing with the life cycles of some helminth species parasitising eels (Moravec 1975, 1996, Moravec et al. 1993, 1994, Scholz 1997, Moravec and Škoríková 1998). The only paper based on a large number (132) of examined eels is that of Moravec (1985) presenting the results of long-term studies on the biology and ecology of endohelminths parasitising eels in the Mácha Lake (= Máchovo jezero) fishpond system in northern Bohemia, in the period before the three important exotic species of helminth parasites, the nematode $A$. crassus and the monogeneans Pseudodactylogyrus anguillae (Yin et Sproston, 1948) and P. bini (Kikuchi, 1929), were introduced into Europe. 
Table 1. List of the localities from where eels, Anguilla anguilla (Linnaeus), were examined.

\begin{tabular}{|c|c|c|c|}
\hline No. & Locality & No. of eels examined & Year(s) and month(s) \\
\hline \multicolumn{4}{|c|}{ ELBE RIVER BASIN (35 localities) } \\
\hline 1 & Elbe River near Hřensko & 13 & 1991, 2001, 2005: V, VI, X \\
\hline 2 & Kamenice River at Hřensko & 8 & 1978, 1979: VII, XI \\
\hline 3 & Ploučnice River near Česká Lípa & 24 & 1994: IX \\
\hline 4 & Ještědský Brook near Ralsko & 9 & 2001, 2002: VI, VIII \\
\hline 5 & Metuje River near Náchod & 5 & 1994: X \\
\hline 6 & Seč water reservoir on the Chrudimka River & 1 & 1975: VIII \\
\hline 7 & Ohře River near Postoloprty & 31 & 1994: X \\
\hline 8 & Libočanský Brook near Žatec & 1 & 2000: VI \\
\hline 9 & Teplá River at Karlovy Vary & 18 & 1963-1967: IV, VI, VII, IX, X \\
\hline 10 & Podhora water reservoir on the Teplá River near Teplá & 16 & 1988: V \\
\hline 11 & Mácha Lake fishpond system near Doksy & 209 & 1965-2008: I-XII \\
\hline 12 & Vltava River near Zbraslav & 13 & 1988: VII \\
\hline 13 & Orlík water reservoir on the Vltava River at Štedronín & 117 & 1994-1997: V, VI, IX-XI \\
\hline 14 & Vltava River near Temelín & 3 & 1988: IX, X \\
\hline 15 & Lipno water reservoir on the Vltava River & 2 & 1999, 2001: IV, V \\
\hline 16 & Upper Vltava River near Lipno (over the Lipno reservoir) & 1 & 1962: XI \\
\hline 17 & Olšina Brook near Horní Planá & 1 & 1962: II \\
\hline 18 & Pond Bagr in České Budějovice & 16 & 1988, 1989: V, VI, VII \\
\hline 19 & Pond Jahelník near Dubné & 1 & 1988: X \\
\hline 20 & Sázava River near Chřenovice & 13 & 1995: VIII \\
\hline 21 & Želivka River near Dolní Kralovice & 9 & 1966, 1967: VI, VII, X \\
\hline 22 & Želivka water reservoir & 31 & 1988, 1995: V, VI \\
\hline 23 & Tisová near Tachov (warm-water aquaculture of eels near the electric power station) & $16^{*}$ & 1989: V \\
\hline 24 & Starý Brook near Kdyně & 22 & 1994: IX \\
\hline 25 & Úhlavka Rivulet near Stř́bro & 7 & 1994: IX \\
\hline 26 & Bílka water reservoir on the Starý Brook near Klatovy & 12 & 1995: V \\
\hline 27 & Otava River near Štědronín & 12 & 1995: VIII \\
\hline 28 & Lužnice River near Tábor & 10 & 1994: V \\
\hline 29 & Lužnice River near Lomnice nad Lužnicí & 11 & 1964-1987: II, III, V-VII \\
\hline 30 & Černovický Brook near Tábor & 1 & 1978: IX \\
\hline 31 & Storage ponds at Třeboň & 7 & 1994: X \\
\hline 32 & Pond Pohorka near Lišov & 4 & 1985: XI \\
\hline 33 & Pond Komorník near Jindřichův Hradec & 1 & 1959: V \\
\hline 34 & Pond Šaloun near Lomnice nad Lužnicí & 10 & 1994: X \\
\hline 35 & Malše River near České Budějovice & 1 & 1984: XI \\
\hline \multicolumn{4}{|c|}{ DANUBE RIVER BASIN (6 localities) } \\
\hline 36 & Rokytná River near Vémyslice & 3 & 1986, 1987: V, VI \\
\hline 37 & Mostiště water reservoir on the Oslava River near Velké Meziříčí & 25 & 1995: V \\
\hline 38 & Fryšták water reservoir near Zlín & 10 & 1994: IX \\
\hline 39 & Kyjovka Rivulet near Koryčany & 11 & 1994: IX \\
\hline 40 & Pond Domaninský near Bystřice nad Pernštejnem & 1 & 1958: XI \\
\hline 41 & Pond Pod mlýnem at Sedlec near Mikulov & 9 & 1995: VI \\
\hline \multicolumn{4}{|c|}{ ODER RIVER BASIN (1 locality) } \\
\hline 42 & Kružberk water reservoir on the Moravice River near Kružberk & 8 & 1996: VI \\
\hline
\end{tabular}

Within broad investigations on the helminth parasites of fishes of the Czech Republic carried out by the researchers of the Institute of Parasitology, Czech Academy of Sciences (previously the Czechoslovak Academy of Sciences), originally in Prague and since 1985 in České Budějovice (see e.g. Moravec 2001, 2013), many eels from different localities were examined during the period of 50 years. Some few partial results of these parasitological examinations have been published (e.g. Ergens 1961, Moravec 1985, Škoríková et al. 1996), but most of the results obtained remain unpublished, even though they represent important information about the species composition of the parasite fauna of eels in the Czech Republic, the distribution of individual species and the diversity of their com- munities in different localities. Based on the high number of eels examined, this paper presents results of probably the most comprehensive studies on the parasites of this important fish. Therefore, the importance of the data accummulated during 50 years in the Czech Republic goes much beyond this Central European country.

\section{MATERIALS AND METHODS}

This paper is principally based on helminthological examinations of eels Anguilla anguilla from the territory of the Czech Republic, carried out at the Institute of Parasitology, Czech Academy of Sciences (previously the Czechoslovak Academy of Sciences) within the period of 50 years (1958-2008). This material includes macroparasites recorded from 25 eels examined by late 


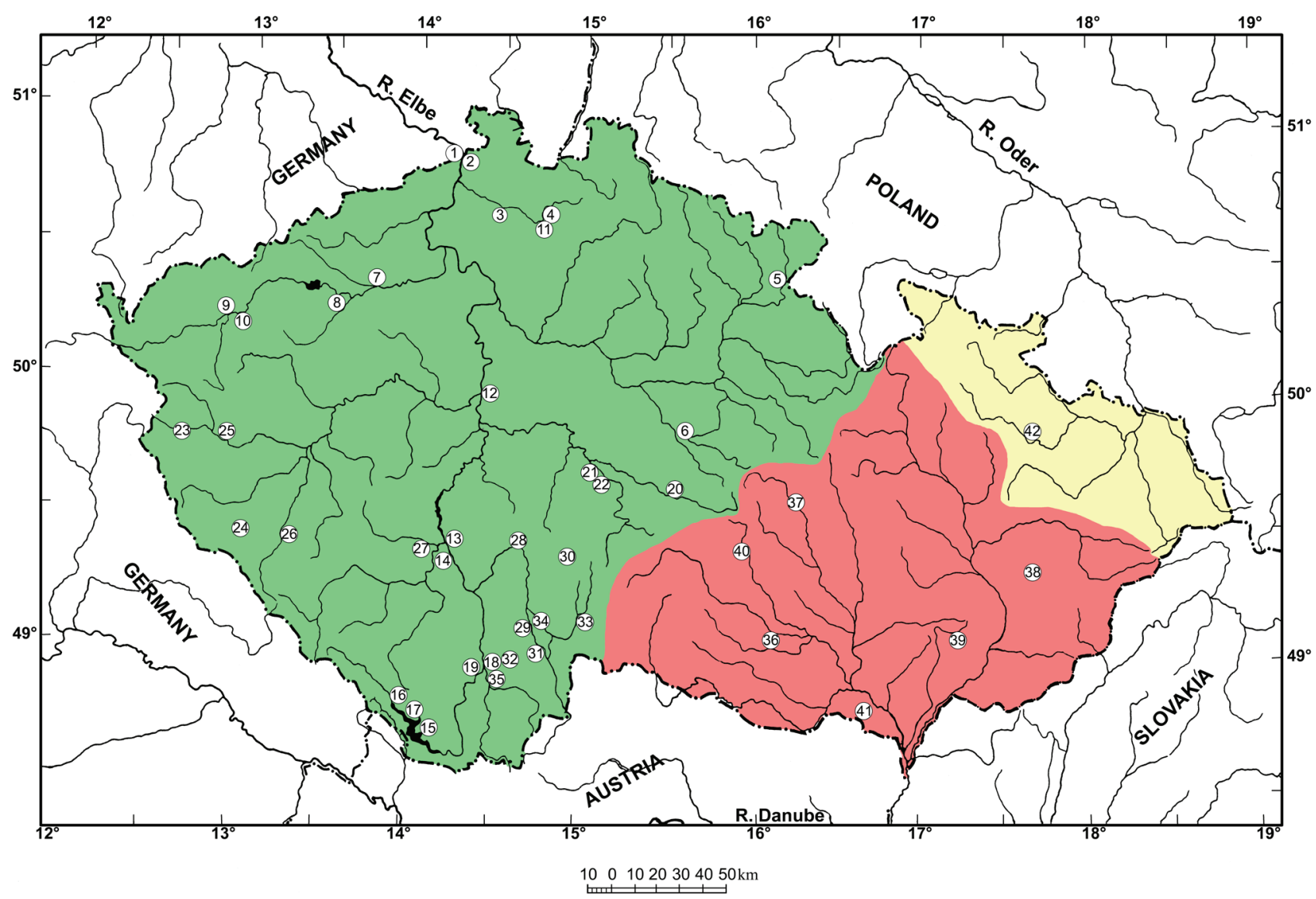

Fig. 1. Map showing sampling sites in the Czech Republic from where the eels were caught (numbers designate the localities listed in Table 1).

Dr. Radim Ergens in 1958-1967, those collected by F. Moravec from 192 eels in the period from 1965-1984 and those collected from 506 eels by F. Moravec and T. Scholz in 1987-2008. Thus, a total of 723 eel specimens was examined from 42 localities that belong to all of the three main river drainage systems in the Czech Republic (see Table 1 and Fig. 1).

The eels were either caught by electro-fishing by the researchers of the Institute or obtained from local fishermen and brought alive to the laboratory, where they were immediately killed and examined fresh. The occurrence of helminths was studied in eels measuring 7-120 $\mathrm{cm}$ by the method of a helminthological dissection with emphasis to endoparasites; the presence of ectoparasites (monogeneans) was not followed in all eel specimens examined. The parasites obtained were treated by usual helminthological methods and these materials are mostly deposited in the Helminthological Collection of the Institute of Parasitology, Biology Centre of the Czech Academy of Sciences, in České Budějovice (http://www.paru.cas.cz/en/collections/). Species of parasites are listed alphabetically in each of the higher taxonomic group.

\section{RESULTS}

\section{Composition of the fauna of macroparasites of Anguilla anguilla in the Czech Republic}

A total of 31 species of macroparasites was found in eels; of these six [Gyrodactylus sp., Crepidostomum metoecus (Braun, 1900), Diplostomum spathaceum (Rudolphi,
1819) metacercariae, Cucullanus truttae Fabricius, 1794, Porrocaecum ensicaudatum (Zeder, 1800) larvae, Echinorhynchus truttae Schrank, 1788 and Argulus foliaceus (Linnaeus, 1758)] represent the first records from eels in the Czech Republic (Table 2).

\section{Monogenea}

\section{Gyrodactylus lucii Kulakovskaya, 1951}

This is a parasite of Esox lucius Linnaeus and some percid fishes. A single specimen of G. lucii was found on the skin of an eel in the Mácha Lake fishpond system (see Moravec 1985) (August 1982, prevalence 1/7, intensity 1); this represents an accidental infection.

\section{Gyrodactylus sp.}

Numerous live and dead specimens of this parasite were found on the gills and fins of eels in the Ohře River near Postoloprty examined in October of 1994, with a prevalence of 26\% (8/31) and intensity 30-300 (mean 94) monogeneans per fish. Probably, A. anguilla is only an accidental host for this parasite.

Pseudodactylogyrus anguillae (Yin et Sproston, 1948) and $\boldsymbol{P}$. bini (Kikuchi, 1929)

In the Elbe River basin, $P$. anguillae alone was recorded from three localities: Sázava River near Chřenovice (August 1995: prevalence 54\% [7/13], intensity 1-12 [mean 
Table 2. Occurrence of macroparasites in Anguilla anguilla (Linnaeus) from three main river basins in the Czech Republic (additional records from other countries are given in parentheses).

\begin{tabular}{|c|c|c|c|}
\hline Parasite & $\begin{array}{l}\text { Elbe River } \\
\text { Basin }\end{array}$ & $\begin{array}{c}\text { Danube } \\
\text { River Basin }\end{array}$ & $\begin{array}{l}\text { Oder River } \\
\text { Basin }\end{array}$ \\
\hline \multicolumn{4}{|l|}{ MONOGENEA } \\
\hline Gyrodactylus lucii & + & & \\
\hline Gyrodactylus sp. & + & & \\
\hline Pseudodactylogyrus anguillae & + & + & \\
\hline Pseudodactylogyrus bini & + & $(+)$ & \\
\hline \multicolumn{4}{|l|}{ TREMATODA } \\
\hline Azygia lucii & + & & \\
\hline Crepidostomum metoecus & + & & \\
\hline $\begin{array}{l}\text { Diplostomum spathaceum larv. } \\
\text { (Metagonimus yokogawai larv.) }\end{array}$ & + & $\begin{array}{c}+ \\
(+) \\
\end{array}$ & \\
\hline \multicolumn{4}{|l|}{ CESTODA } \\
\hline Bothriocephalus claviceps & + & + & + \\
\hline Proteocephalus macrocephalus & + & + & \\
\hline Triaenophorus nodulosus juv. & + & $(+)$ & \\
\hline \multicolumn{4}{|l|}{ NEMATODA } \\
\hline Anguillicoloides crassus & + & + & \\
\hline Camallanus lacustris & + & & \\
\hline Camallanus truncatus & & + & \\
\hline Cucullanus truttae & + & & \\
\hline Daniconema anguillae & + & $(+)$ & \\
\hline (Hedruris androphora) & & $(+)$ & \\
\hline Paraquimperia tenerrima & + & + & \\
\hline Raphidascaris acus & + & $(+)$ & \\
\hline Salmonema ephemeridarum & + & & \\
\hline Spinitectus inermis & + & & \\
\hline Eustrongylides mergorum larv. & + & & \\
\hline Porrocaecum ensicaudatum larv. & + & & \\
\hline \multicolumn{4}{|l|}{ ACANTHOCEPHALA } \\
\hline Acanthocephalus anguillae & + & $(+)$ & \\
\hline Acanthocephalus lucii & + & + & + \\
\hline Echinorhynchus truttae & + & & \\
\hline $\begin{array}{l}\text { Neoechinorhynchus rutili } \\
\text { (Paratenuisentis ambiguus) }\end{array}$ & $\begin{array}{c}+ \\
(+)\end{array}$ & + & \\
\hline Pomphorhynchus laevis & & + & \\
\hline
\end{tabular}

HIRUDINEA

Piscicola geometra

BIVALVIA

Glochidium gen. sp. larv. ++

COPEPODA

\begin{tabular}{lcc}
\hline Ergasilus gibbus $(?)$ & + & $(+)$ \\
Ergasilus sieboldti & + & + \\
\hline
\end{tabular}

BRANCHIURA

Argulus foliaceus

ACARIFORMES

Hydrozetes sp.

(?) - the only species previously reported from this host and not confirmed in the present paper is Ergasilus gibbus Nordmann, 1832 (see Frič 1873, Moravec 2001).

5]); Želivka water reservoir (June 1995: 30\% [6/20], 1-6 [3]); and Metuje River near Náchod (October 1994: [4/5], 1-9 [5]). Pseudodactylogyrus bini alone was found in one locality: Ploučnice River near Česká Lípa (September 1994: 90\% [9/10], 85-1451 [536]). However, both $P$. anguillae and $P$. bini occurred in co-infections on gills in the following Bohemian localities, where the proportions of both species in samples were similar: Mácha Lake fishpond system (a sample of 16 eels in August 1994; not recorded in previous years) (prevalence of both species together 88\% [14/16], intensity 9-330 [55]); Orlík water reservoir (September 1994: 7/9, 3-25 [7], October 1994: $80 \%$ [12/15], 1-290 [64], September 1995: 87\% [20/23], 1-368 [37], May 1996: 36\% [5/14], 1-28 [11], June 1996: 36\% [4/11], 1-24 [11], October 1996: 67\% [10/15], 9-87 [31]); Lužnice River near Tábor (May 1994: 20\% [2/10], 2-93 [48]); Otava River near Štědronín (August 1995: 100\% [12/12], 2-158 [69]); Úhlavka Rivulet near Stř́bro (September 1994: [6/7], 3-61 [30]); and Ohře River near Postoloprty (October 1994: 32\% [10/31], 2-12 [5]).

In the Danube River basin, $P$. anguillae alone was recorded in one locality: Fryšták water reservoir near Zlín (September 1994: 40\% [4/10], 3-65 [21]).

However, the presence of these parasites in other localities cannot be excluded, because no attention was paid to monogenean infections of eels in some localities.

Both $P$. anguillae and $P$. bini are pathogenic gill parasites of the Japanese eel Anguilla japonica Temminck et Schlegel in East Asia, from where they were introduced into Europe in the 1970's. In Europe they quickly spread in the populations of the European eel A. anguilla (see Škoríková et al. 1996). The first record of both parasite species in the former Czechoslovakia is that of late R. Ergens (Institute of Parasitology, Biology Centre, ASCR, České Budějovice, CR - unpubl. data) in October of 1989, who found them to be abundant on small eels (body length 7-18 cm) in a warm-water aquaculture at Tisová, North Bohemia (see Škoríková et al. 1996). The present data show that now both $P$. anguillae and $P$. bini are widespread in eel populations in the Czech Republic. Although these parasites were not recorded in 132 eels in the Mácha Lake fishpond system examined until 1977 (Moravec 1985), a sample of eels from the same locality examined in 1994 showed high levels of infection with $P$. anguillae and $P$. bini. The situation in this locality reflects the spreading of these parasites in Europe, because the first record of both species in Europe was that of Golovin (1977) in Russia.

\section{Trematoda}

\section{Azygia lucii (Müller, 1776)}

This trematode was found in the stomach of eels in two localities belonging to the Elbe River basin: Mácha Lake fishpond system near Doksy (April 1971: 1/1, 1; September 1971: 7\% [1/14], 1; May 1982: 1/5, 1; June 1982: 8\% [1/12], 3; August 1994: 13\% [2/16], 1); and Orlík water reservoir near Štědronín (September 1995: 3\% [1/38], 9). Azygia lucii was previously reported from eels in the former locality by Moravec (1985).

The principal definitive host of $A$. lucii is the northern pike, Esox lucius, whereas the European eel serves only as a subsidiary host. It may be supposed that $A$. anguilla acquires the infection by swallowing infected fish, mainly small pike and perch. The occurrence of A. lucii in eels seems to be in correlation with the feeding period of the 
fish: during the cold season, when the feeding activity of eels almost ceases (Lacey et al. 1982), A. lucii was not recorded. In addition to A. anguilla, Perca fluviatilis Linnaeus and Sander lucioperca (Linnaeus) were also recorded as subsidiary hosts of $A$. lucii in the Mácha Lake fishpond system (Moravec 1985).

According to Odening (1976), intermediate hosts of A. lucii are various species of freshwater snails of the families Planorbidae, Lymnaeidae, Physidae and Valvatidae.

\section{Crepidostomum metoecus (Braun, 1900)}

The only locality where this trematode was found in the intestine of an eel was the Ještědský Brook near Ralsko (August 2001: 1/6, 1), belonging to the Elbe River basin.

The main definitive hosts of $C$. metoecus are salmonids, in Europe mostly the brown trout, Salmo trutta fario Linnaeus (see Moravec 2004). It is also reported from predatory fishes of some other families such as Esox lucius (Esocidae), Lota lota (Linnaeus) (Lotidae) or Perca fluviatilis (Percidae), which, undoubtedly, acquire the infection of adult trematodes while feeding on small salmonids (Moravec 2004). The finding of adult C. metoecus in A. anguilla suggests a similar way of transmission, i.e. that the eels acquire this trematode by swallowing small-sized infected trout. In the same locality, C. metoecus was recorded from $40 \%$ of $S$. trutta fario examined (Moravec 2003). The first intermediate hosts of C. metoecus are bivalves (Pisidium spp.); amphipods [Gammarus pulex (Linnaeus)] and nymphs of aquatic insects (Ephemera Linnaeus, Cloeon Leach, Siphlonurus Eaton) were recorded as its second intermediate hosts in Europe (see Moravec 2004).

\section{Diplostomum spathaceum (Rudolphi, 1819) larv.}

Metacercariae of this trematode located in the eye lens of eels were recorded from the following localities belonging to two main river drainage systems.

Elbe River basin: Lužnice River near Lomnice nad Lužnicí (March 1987: 1/1, 1); Podhora water reservoir on the Teplá River near Teplá (May 1987: 6\% [1/16], 1); Vltava River near Zbraslav (July 1988: 8\% [1/13], 1); Vltava River near Temelín (September 1988: 1/1, 1; October 1988: 1/2, 1); pond Bagr in České Budějovice (November 1988: 1/3, 1; May 1989: 45\% [5/11], 1-4 [2]); Orlík water reservoir near Štědronín (June 1994: 1/9, 1; October 1994: 47\% [7/15], 1-5 [3]; September 1995: 57\% [13/23], 1-4 [2]; May 1996: 21\% [3/14], 1-14 [6]; June 1996: 27\% [3/11], 1-2 [2]; October 1996: 47\% [7/15], 1-6 [2]); Ploučnice River near Česká Lípa (November 1994: 8\% [2/24], 1); Ohře River near Postoloprty (October 1994: 10\% [3/31], 1); Mácha Lake fishpond system (September 1995: 9\% [2/22], 1-2 [1]).

Danube River basin: Fryšták water reservoir near Zlín (November 1994: 40\% [4/10], 1-2 [1]); pond Pod mlýnem at Sedlec near Mikulov (June 1995: 3/9, 1-2 [1]).

In the Czech Republic, adults of D. spathaceum are common intestinal parasites of gulls (Larus spp.) and are exceptionally found in other birds. The first intermediate host is the freshwater snail Lymnaea (Radix) peregra ovata (Draparnaud); many fish species belonging to dif- ferent families (rarely also frogs) serve as the second intermediate host (Vojtek 1974, Moravec 2001, Sitko et al. 2006). According to Moravec (2001), metacercariae of D. spathaceum were previously recorded from 50 fish species (mainly cyprinids) in the former Czechoslovakia, but not from $A$. anguilla. Consequently, the present findings of these parasites in eels represent a new host record.

Taxonomic note: The taxonomy of species of Diplostomum von Nordmann, 1832, including identification of their metacercariae and specificity to the second intermediate host, are not fully resolved. In addition, recent taxonomic studies that combined molecular and morphological data have revealed cryptic diversity in the Diplostomum species complex (see e.g. Georgieva et al. 2013, Blasco-Costa et al. 2014, Faltýnková et al. 2014). Therefore, it may well be that metacercariae from eels reported under the name D. spathaceum actually belong to more than one species of Diplostomum.

\section{Cestoda}

\section{Bothriocephalus claviceps (Goeze, 1782)}

This cestode was recorded from eels in the following localities belonging to all three main river drainage systems:

Elbe River basin: pond Komorník near Jindřichův Hradec (May 1964: prevalence 1/1, intensity 32); Lužnice River near Tábor (May 1964: 1/2, 5; August 1980: 2/2, 1-3 [2]; May 1981: 1/1, 1; February and March 1987: 2/2, 1-2 [2]); Mácha Lake fishpond system near Doksy (February 1967: 1/1, 6; April 1976: 2/9, 1-3 [2]; May 1976: 1/2, 2; August 1976: 1/1, 8; September 1976: 2/5, 1; October 1976: 2/4, 1-16 [9]; December 1976: 2/5, 8-12 [10]; September 1977: 43\% [6/14], 1-23 [7]; April 1981: 1/1, 1; May 1981: 1/2, 7; June 1981: 3/6, 1-6 [3]; July 1981: 1/1, 1; September 1981: 1/2, 14; February 1982: 1/3, 18; March 1982: 6/9, 1-32 [8]; April 1982: 5/7, 1-42 [16]; Мay 1982: 1/5, 3; June 1982: 58\% [7/12], 1-5 [2]; July 1982: 7/9, 1-112 [23]; August 1982: 4/7, 1-58 [17]; September 1982: 3/8, 2-3 [2]; October 1982: 2/5, 4-6 [5]; September 1990: 2/5, 1-4 [2]; August 1994: 38\% [6/16], 1-4 [2]; September 1995: 18\% [4/22], 1-13 [5]; June 2003: 1/1, 15; December 2008: 1/3, 1); pond Pohorka near Lišov (November 1985: 2/4, 2-10 [6]); Podhora water reservoir on the Teplá River (May 1988: 19\% [3/16], 1-2 [2]); Vltava River near Temelín (September 1988: 1/1, 5); pond Bagr at České Budějovice (June 1988: 1/2, 3; May 1989: 9\% [1/11], 1); pond Šaloun near Lomnice nad Lužnicí (October 1994: 20\% [2/10], 2-4 [3]); Ploučnice River near Česká Lípa (September 1994: 33\% [8/24], 1-25 [5]; Ohře River near Postoloprty (October 1994: 23\% [7/31], 1-4 [1]); Orlík water reservoir (October 1994: 20\% [3/15], 1-3 [2]; September 1995: 1/7, 3; May 1996: 36\% [5/14], 2-17 [6]; October 1996: 40\% [6/15], 1-2 [1]; June 1997: 29\% 4/14, 1-2 [1]; October 1997: 19\% [3/16], 1-4 [3]); storage ponds at Třeboň (October 1994: 2/7, 2-4 [3]; Starý Brook near Klatovy (8\% [1/12], 1); Želivka water reservoir (June 1995: 10\% 2/20, 1-9 [5]; Sázava River near Chřenovice (August 1995: 8\% [1/13], 1); Libočanský Brook near Žatec (June 2000: 1/1, 15). 
Danube River basin: pond Domaninský near Bystřice nad Pernštejnem (November 1958: 1/2, 1); Rokytná River near Vémyslice (June 1987: 1/1, 1); Kyjovka Rivulet near Koryčany (September 1994: 18\% [2/11], 2-5 [4]); Fryšták water reservoir near Zlín (September 1994: 30\% [3/10], 1); Mostiště water reservoir on the Oslava River near Velké Meziř́č́í (May 1995: 16\% [4/25], 1-4 [2]).

Oder River basin: Kružberk water reservoir on the Moravice River near Kružberk (June 1996: 5/8, 1-12 [3]).

Bothriocephalus claviceps was previously reported from eels in the localities of the Elbe and Danube Rivers basins in the Czech Republic by Šámek (1901), Frič (1908), Lucký (1953), Volf and Smíšek (1955), Vojtková (1959), Ergens (1961), Dyk and Lucký (1963), Ergens and Lom (1970), Moravec (1978, 1985), Scholz (1989) and Gelnar et al. (1990).

The present data show that $B$. claviceps is a common and widespread parasite in the Czech Republic, occurring in eels all the year round. Although it is also present in slowly flowing waters, its highest prevalence was found in larger still-water bodies, such as water reservoirs (Orlík and Fryšták water reservoirs up to about $40 \%$ and $30 \%$, respectively, or Kružberk water reservoir where 5 of 8 eels examined were infected) or large pond systems (Mácha Lake fishpond system up to about $80 \%$ ). The finding of B. claviceps in the Kružberk reservoir represents the first documented record of this parasite in the Oder River basin in the Czech Republic.

This cestode seems to be a specific intestinal parasite of eels and $A$. anguilla has so far been recorded as the only fish definitive host of this species in the Czech Republic (Moravec 2001; present data). Bothriocephalus claviceps has also been reported from fish species belonging to other families, but these probably do not serve as true definitive hosts (Scholz 1997). In this connection, it is necessary to mention an interesting finding of adult $B$. claviceps from the intestine of $15 \%$ of newts Triturus vulgaris (Linnaeus) (Caudata) in the small South Bohemian pond Bagr examined in the spring of 1988 and 1989, where also eels infected by this parasite co-occurred (Scholz and Moravec 1990). However, no oncosphere development was observed during laboratory experiments with the cultivation of these eggs, indicating that only non-viable eggs are produced by these cestodes in their atypical amphibian host (newt).

The source of $B$. claviceps infection for eels are either copepod intermediate hosts or forage fishes serving as paratenic hosts (Jarecka 1959, 1963, 1964, Moravec 1985, Dupont and Gabrion 1986, Scholz 1986, 1987, 1997). The population biology of this cestode in eels of the Mácha Lake fishpond system was studied by Moravec (1985), who found that the highest values of prevalence and mean intensity occurred in eels $30-45 \mathrm{~cm}$ long and that B. claviceps exhibits a pronounced seasonal maturation cycle with the oviposition in the period from June until August; the only fish paratenic host in this locality was found to be small perch, Perca fluviatilis (see Scholz 1986, 1987). Also according to Nie and Kennedy (1992), B. claviceps reaches maximum size and becomes gravid mainly in summer in three localities in southwestern England. However, the maturation cycles of B. claviceps, subjecting to many local ecological factors, may be very different in other localities; accordingly, gravid cestodes may be found in other months or nearly throughout the year in different localities (e.g. Lucký 1953, Kažić 1970, Chubb 1982, Moravec 1985).

\section{Proteocephalus macrocephalus (Creplin, 1825)}

This species was recorded from the following localities belonging to the Elbe and Danube River drainage systems:

Elbe River basin: Lužnice River near Lomnice nad Lužnicí (May 1964: 1/2, 1; August 1980: 1/2, 1; February 1987: 1/1, 7; March 1987: 1/1, 26; May 1987: 2/2, 1-13 [7]); Podhora water reservoir on the Teplá River near Teplá (May 1988: 19\% [3/16], 1); Vltava River near Temelín (September 1988: 1/1, 6); pond Bagr in České Budějovice (November 1988: 1/4, 1); Lužnice River near Tábor (May 1994: 40\% [4/10], 1-9 [6]); Orlík water reservoir on the Vltava River near Štědronín (June 1994: 3/9, 2-3 [2]; October 1994: 27\% [4/15], 1-11 [4]; September 1995: 22\% [5/23], 1-42 [10]; May 1996: 36\% [5/14], 2-17 [6]; June 1996: 45\% [5/11], 1-32 [7]; October 1996: 80\% [12/15], 1-69 [16]; June 1997: 36\% [5/14], 1-4 [2]; October 1997: $19 \%$ [3/16], 5-10 [8]); storage ponds at Třeboň (October 1994: 5/7, 1-96 [45]); Ohře River near Postoloprty (October 1994: 16\% [5/31], 1-2 [1]); pond Šaloun near Lomnice nad Lužnicí (October 1994: 70\% [7/10], 1-41 [13]); Želivka water reservoir (June 1995: 65\% [13/20], 1-12 [4]); Sázava River near Chřenovice (August 1995: 23\% [3/13], 2-10 [5]); Otava River near Štědronín (August 1995: 58\% [7/12], 2-5 [4]); Mácha Lake fishpond system near Doksy (December 2008: 1/3, 3).

Danube River basin: Fryšták water reservoir near Zlín (September 1994: 30\% [3/10], 1-7 [4]).

In the Czech Republic, this parasite has previously been reported from a few localities belonging to the Elbe River basin (Scholz and Kepr 1988, Scholz 1989, Moravec et al. 1997, Scholz et al. 1997, 1998, Scholz and Hanzelová 1998, Žd'árská and Nebesářová 1999a, b). This paper provides the first report from the Danube River basin. The present data indicate that $P$. macrocephalus is a common and widespread cestode species in the Czech Republic, occurring in eels mainly in larger rivers, water reservoirs and ponds. The highest prevalence (up to $80 \%$ ) and intensity (up to 69 specimens) were recorded in the Orlík water reservoir in October 1996, but high levels of infection were also found in some other localities.

This cestode is a specific intestinal parasite of eels ( $\mathrm{An}$ guilla spp.). The source of $P$. macrocephalus infection for eels are probably both infected copepod intermediate hosts and small forage fishes serving as paratenic hosts (Doby and Jarecka 1966, Willemse 1967, Scholz et al. 1997). It can be assumed that $P$. macrocephalus, as most other proteocephalideans of the temperate zone, exhibits a pronounced seasonal maturation cycle, but no detailed data on the population biology of this species are available. According to Nie and Kennedy (1991a), growth and maturation of $P$. macrocephalus occurred in early summer in two small rivers in England. At Lake Skadar, Montenegro, 
Kažić (1970) recorded mature $P$. macrocephalus in $A$. anguilla from January to July and in November, and immature worms during all months, with the highest numbers in May, August and December.

\section{Triaenophorus nodulosus (Pallas, 1781) juv.}

Juvenile specimens of this species were recorded from the intestines of eels only twice in two localities belonging to the Elbe River basin: Teplá River at Karlovy Vary (July 1965: 1/6, 1) and Mácha Lake fishpond system (August 1994: 6\% [1/16], 1). Apparently, eels acquired the infection while feeding on other fishes (probably small $P$. $f u$ viatilis) harbouring the cestode plerocercoids and serving as the second intermediate host of $T$. nodulosus. Larval $T$. nodulosus in A. anguilla was previously reported by Vojtek (1961) in the former Czechoslovakia (locality not given) (see also Macko et al. 1993).

\section{Nematoda}

Anguillicoloides crassus Kuwahara, Niimi et Itagaki, 1974

This swimbladder nematode was recorded from the following localities belonging to two main river drainage systems.

Elbe River basin: Elbe River near Hřensko (June 1991: 80\% [8/10], 1-7 [4]; October 2001: 1/1, 1; May 2005: 1/1, 1); Lužnice River near Tábor (May 1994: 10\% [1/10], 8); Orlík water reservoir near Štědronín (June 1994: 2/9, 3 [3]; October 1994: 60\% [9/15], 1-18 [6]; September 1995: 78\% [18/23], 1-73 [21]; May 1996: 43\% [6/14], 6-48 [20]; June 1996: 27\% [3/11], 14-62 [37]; October 1996: 80\% [12/15], 4-31 [19]; June 1997: 57\% [8/14], 2-29 [10]; October 1997: 50\% [8/16], 13-110 [40]); Ohře River near Postoloprty (October 1994: 6\% [2/31], 1-2 [2]); Otava River near Štědronín (August 1995: 92\% [11/12], 1-77 [26]); Ještědský Brook near Ralsko (August 2001: 1/6, 8; June 2002: 1/3, 3); Mácha Lake fishpond system (March 2003: 1/1, 11; April 2003: 1/2, 10; May 2003: 3/3, 3-11 [7]; June 2003: 1/1, 31; December 2004: 1/2, 29; December 2008: 3/3, 5-26 [14]).

Danube River basin: Kyjovka Rivulet near Koryčany (September 1994: 45\% [5/11], 1-11 [5]); pond Pod mlýnem in Sedlec near Mikulov (June 1995: 4/9, 3-5 [4]).

This pathogenic parasite of eels was introduced from the Far East into Germany in 1982 (Neumann 1985), from where it quickly spread throughout Europe. Taraschewski et al. (1987) reported it from localities in northern Germany that belong to three main river drainage systems, including the Elbe River estuary. In the Czech Republic, A. crassus was first recorded from eels in the Elbe River near Hřensko in June 1991 (Moravec 1992) and later also found in some other localities including those belonging to the Danube basin (Baruš et al. 1996, Moravec 2001). In the Czech Republic, it has not yet been recorded from the Oder River basin, where, however, eels occur rather rarely.

The life cycle of $A$. crassus involves a copepod or ostracod intermediate host and various aquatic invertebrates (insect larvae, snails) and vertebrates (fishes, amphibians) that serve as paratenic hosts. Eels acquire $A$. crassus infection by feeding on both intermediate- and paratenic hosts, particularly small fishes harbouring $A$. crassus third-stage larvae (Moravec 2013).

\section{Camallanus lacustris (Zoega, 1776)}

This species was found in eels only in localities belonging to the Elbe River basin: Mácha Lake fishpond system (February 1967: 1/1, 235; November 1975: 1/1, 1; April 1976: 2/8, 1; May 1976: 1/2, 4; June 1976: 1/3, 1; September 1976: 4/5, 7-51 [17]; December 1976: 3/5, 2-26 [11]; April 1977: 1/1, 1; May 1977: 1/2, 4; September 1977: 50\% [7/14], 1-24 [5]; July 1981: 1/1, 2; September 1981: 1/2, 2; February 1982: 1/3, 1; March 1982: 6/8, 1-8 [3]; April 1982: 5/8, 1-10 [3]; May 1982: 1/5, 8; June 1982: 42\% [5/12], 2-9 [5]; July 1982: 3/9, 2-7 [4]; August 1982: 2/7, 2-5 [4]; September 1982: 4/8, 1-4 [3]; October 1982: 2/5, 2-5 [4]; May 1987: 31\% [5/16], 3-15 [7]; May 1990: 2/3, 2-7 [5]; August 1994: 44\% [7/16], 1-5 [2]; September 1995: 41\% [9/22], 1-43 [11]; December 2000: 2/3, 3-6 [3]; March 2003: 1/1, 18; May 2003: 1/2, 2; June 2003: 1/1, 2; December 2004: 1/2, 1; December 2005: 2/3, 3-6 [5]); pond Pohorka near Lišov (November 1985: 1/4, 3); Želivka water reservoir (May 1988: 55\% [6/11], 1-12 [6]; June 1995: 20\% [4/20], 1-2 [2] ); Podhora water reservoir on the Teplá River near Teplá (May 1988: 6\% [1/16], 4); pond Bagr in České Budějovice (November 1988: 2/4, 1-3 [2]; May 1989: 18\% [2/11], 1-3 [2]); Lužnice River near Tábor (May 1994: 10\% [1/10], 3); Ploučnice River near Česká Lípa (September 1994: 25\% [6/24], 1-15 [5]); Ohře River near Postoloprty (October 1994: 19\% [6/31], 1-19 [6]); Orlík water reservoir near Štědronín (October 1994: 7\% [1/15], 6; September 1995: 6\% [1/16], 1; May 1996: 7\% [1/14, 1; October 1996: 13\% [2/15], 1; June 1997: 7\% [1/14], 2; October 1997: 13\% [2/16], 18-20 [19]); Otava River near Štědronín (August 1995: 17\% [2/12], 1-3 [2]); Ještědský Brook near Ralsko (August 2001: 1/6, 1).

The nematode $C$. lacustris parasitises predominantly fishes of the family Percidae, particularly Perca fluviatilis, which serve as definitive hosts. In addition to percids, it is often found in fishes of other families (especially in predatory species), serving apparently only as paradefinitive or postcyclic hosts (Moravec 2013). It remains unknown whether the infective larvae of $C$. lacustris may develop further and attain maturity in A. anguilla, but eels often harboured gravid (larvigerous) females of this parasite. In the present Czech Republic, this parasite was previously reported from eels in the Elbe River basin (Vltava River in Prague, Elbe River in Poděbrady, Mácha Lake fishpond system) (John 1877, Šrámek 1901, Moravec 1978).

Moravec (1985) observed in eels from the Mácha Lake fishpond system that the values of $C$. lacustris prevalence and mean intensity markedly increased with the body size of this fish host; the highest intensity of infection (235 nematodes) was recorded in an eel measuring $120 \mathrm{~cm}$ in length. The intermediate hosts of $C$. lacustris are various species of copepods, whereas some small fishes serve as paratenic hosts (Moravec 2013). Apparently the main source of $C$. lacustris infections in eels is some prey fishes, 
particularly small perch. This parasite does not seem to exhibit a pronounced seasonal cycle of maturation (Moravec 1979b, Scholz 1986) and its different developmental stages occurred in eels throughout the year (Moravec 1985).

\section{Camallanus truncatus (Rudolphi, 1814)}

This species was found only in localities belonging to the Danube River basin: Kyjovka Rivulet near Koryčany (September 1994: 45\% [5/11], 1-2 [1]); and Mostiště water reservoir on the Oslava River near Velké Meziříčí (May 1995: 4\% [1/25], 1).

The principal definitive hosts of $C$. truncatus seem to be fishes of the genus Sander Oken ( $S$. lucioperca and $S$. volgensis Gmelin), but it occurs as well in other percids. Similarly to $C$. lacustris, $C$. truncatus also occurs in many fish species of different families serving probably only as paratenic or postcyclic hosts. In the Danube River basin of the Czech Republic, this parasite was previously recorded from eels in the Svratka River in Brno by Vojtková (1959).

The intermediate hosts of C. truncatus are various species of copepods, whereas some small fishes serve as paratenic hosts (Moravec 2013); the latter are probably the main source of infection for eels.

\section{Cucullanus truttae Fabricius, 1794}

Adults of this species (including ovigerous females) were recorded from eels in one locality belonging to the Elbe River basin: Ještědský Brook near Ralsko (June 2001: 3/3, 1-6 [3]).

Cucullanus truttae is an intestinal parasite of salmonids, in Europe mainly of the brown trout Salmo trutta fario. Rarely this species was recorded from some predatory fishes of other families, such as Perca fluviatilis or Lota lota, which probably act only as postcyclic hosts (Moravec 2013). Previously, C. truttae was recorded from eels only in Sweden, Ireland, England and Portugal (Törnquist 1931, Conneely and McCarthy 1986, Kennedy 2001, Saraiva et al. 2005). Apparently, also in these cases, eels acquired the C. truttae infection secondarily while occasional preying upon the definitive fish hosts of this nematode.

The intermediate hosts of $C$. truttae are larvae of different species of lampreys, in the Czech Republic only the brook lamprey Lampetra planeri (Bloch). However, after the metamorphosis of infected lampreys, the development of $C$. truttae larvae continues further in adult lampreys, in which the nematodes attain their full maturity and may produce eggs (Moravec 2013). Judging from the body size (length $42-54 \mathrm{~cm}$ ) of eels infected with $C$. truttae in the Ještědský Brook and because the nematodes from eels included ovigerous females, it is almost certain that the source of infection for eels was infected adult lampreys. According to the observations of Moravec (1980), C. truttae is found only in brown trout longer than $21 \mathrm{~cm}$; consequently, trouts of this size cannot become a prey for eels.

\section{Daniconema anguillae Moravec et Køie, 1987}

This parasite of the serosa of swimbladder and intestine of eels was recorded from the localities belonging to the Elbe River basin: Mácha Lake fishpond system (June
1981: 8\% [1/12], 1; May 1987: 7\% [1/15], 1; August 1994: 25\% [4/16], 1-23 [7]; September 1995: 14\% [3/22], 1-2 [1]); Ploučnice River near Česká Lípa (September 1994: 4\% [1/24], 1); Ohře River near Postoloprty (October 1994: 3\% [1/31], 1); Sázava River near Chřenovice (August 1995: 8\% [1/13], 1).

Daniconema anguillae is a Holarctic parasite of eels, occurring only in A. anguilla in Europe and in A. rostrata (LeSeuer) in North America. In Europe, it has been reported only from the Czech Republic, Denmark, Hungary and Lithuania (see Moravec 2013). Its life cycle is unknown, but it may be similar to that in the nematodes of the family Skrjabillanidae, i.e. that the intermediate hosts are bloodsucking branchiurids (Argulus spp.), which may be also the source of $D$. anguillae infection for eels. The third-stage larvae of $D$. anguillae occur, sometimes in considerable numbers, in the fins and subcutaneous connective tissue of infected eels (Molnár and Moravec 1994, Molnár and Székely 1995).

\section{Paraquimperia tenerrima (Linstow, 1878)}

This nematode was recorded from the following localities:

Elbe River basin: Teplá River at Karlovy Vary (October 1963: 1/3, 5; October 1964: 1/2, 1; July 1965: 5/6, 1-11 [4]; September 1965: 1/1, 6; June 1966: 3/3, 1-2 [2]; June 1967: 1/2, 8); Želivka River near Dolní Kralovice (July 1966: 5/6, 2-5 [3]; June 1967: 1/1, 5); Kamenice River near Hřensko (November 1978: 3/5, 1-4 [2]; November 1979: 1/3, 1); Lužnice River near Lomnice nad Lužnicí (August 1980: 1/2, 1); Vltava River near Zbraslav (July 1988: 8\% [1/13], 2); Orlík water reservoir near Štědronín (June 1994: 1/9, 7; October 1994: 27\% [4/15], 1-14 [7]; September 1995: 4\% [1/23], 2; June 1996: 9\% [1/11], 14; October 1996: 7\% [1/15], 2; June 1997: 7\% [1/14], 1; October 1997: 6\% [1/16], 1); Ploučnice River near Česká Lípa (September 1994: 58\% [14/24], 1-7 [3]); Starý Brook near Kdyně (September 1994: 59\% [13/22], 1-11 [4]); Úhlavka Rivulet near Stř́bro (September 1994: 3/7, 1-13 [8]); Ohře River near Postoloprty (October 1994: 61\% [19/31], 1-6 [3]); Bílka water reservoir on the Starý Brook near Klatovy (May 1995: 42\% [5/12], 1-6 [4]); Sázava River near Chřenovice (August 1995: 62\% [8/13], 1-24 [9]); Otava River near Štědronín (August 1995: 8\% [1/12], 1); Ještědský Brook near Ralsko (October 2001: 5/6, 1-14 [5]).

Danube River basin: Rokytná River near Vémyslice (May 1986: 2/2, 1-9 [5]; June 1987: 1/1, 1).

This nematode is a specific intestinal parasite of $A$. anguilla, which is widely distributed in Europe (Moravec 2013). In the Czech Republic, P. tenerrima was first recorded by Šramek (1901) from eels in the Elbe River at Poděbrady. It occurs mainly in small streams and rivers, where it exhibits seasonal cycles of occurrence and maturation (Chubb 1975, Nie and Kennedy 1991b). In the Czech Republic, P. tenerrima was recorded from eels during May-July and in September and always gravid females with eggs were also present. The life cycle of $P$. tenerrima remains insufficiently known. Probably aquatic insect larvae, crustaceans or small fishes 
serve as intermediate or paratenic hosts (Moravec 1975, 2013, Shears and Kennedy 2005).

\section{Raphidascaris acus (Bloch, 1779)}

Adults of R. acus and larvae in the intestinal lumen of eels were found in the following localities belonging to one main river drainage system.

Elbe River basin: Teplá River at Karlovy Vary (October 1964: $1 / 2$, 1; July 1965: 1/6, 3; September 1965: 1/1, 2; June 1966: 1/3, 3; June 1967: 1/3, 1); Mácha Lake fishpond system (September 1976: 2/5, 2-27 [15]; May 1977: 1/2, 1; September 1977: 7\% [1/14], 1; December 1977: 1/1, 1; December 1981: 1/1, 1; September 1990: 1/5, 1); Lužnice River near Lomnice nad Lužnicí (May 1987: 1/2, 2); Vltava River near Zbraslav (July 1988: 31\% [4/13], 1-3 [2]); Vltava River near Temelín (October 1988: 1/1, 1); Kamenice River near Hřensko (June 1991: 1/1, 3); Lužnice River near Tábor (May 1994: 30\% [3/10], 2-18 [10]; Orlík water reservoir near Štědronín (June 1994: 1/9, 1; October 1994: 1/7, 1; May 1996: 7\% [1/14], 1); Úhlavka Rivulet near Stř́ibro (September 1994: 2/7, 1-2 [2]); Ohře River near Postoloprty (October 1994: 26\% [8/31], 1-39 [7]); Libočanský potok near Žatec (June 2000: 1/1, 23); Ještědský Brook near Ralsko (August 2001: 1/6, 1).

Raphidascaris acus is a common and widespread parasite in the Czech Republic, where both its adults and larvae have been reported from many fish species in all three main river drainage systems (Moravec 2001). The definitive hosts of $R$. acus are piscivorous fishes belonging to different families, in Europe mainly the pike Esox lucius and the brown trout Salmo trutta fario, less often other species of salmonids, Lota lota, Perca fluviatilis, Sander lucioperca or Anguilla anguilla (see Moravec 2013). However, in addition that eels may serve as definitive hosts for this nematode species, they may also become (as many other fish species) its intermediate hosts: Moravec (1985) recorded 27 encapsulated infective $R$. acus larvae from a single eel (body length $40 \mathrm{~cm}$ ) of 132 examined in the Mácha Lake fishpond system.

The intermediate hosts of $R$. acus are very many fish species and, in some localities, also amphipods of the genus Gammarus Fabricius, which are the source of infection for the definitive host. However, there is also a variety of aquatic invertebrate pre-intermediate and vertebrate postintermediate paratenic hosts of $R$. acus, of which the latter (mainly fishes and some amphibians) may also serve as source of infection for the definitive host (see Moravec 2013). Adults of $R$. acus (including ovigerous females) were recorded in eels only during late spring and early autumn, whereas samples collected in other seasons comprised intestinal third- or fourth-stage larvae. This corresponds to the pronounced seasonal maturation cycle of $R$. acus observed in other definitive hosts in different localities (Moravec 2013).

Salmonema ephemeridarum (Linstow, 1872)

This nematode was found in an eel only once in a locality belonging to the Elbe River basin: Teplá River in
Karlovy Vary (July 1965: 1/3, 1). This finding was already reported by Moravec (1967).

The nematode $S$. ephemeridarum is a stomach parasite of salmonids, in Europe mainly of the brown trout Salmo trutta fario (see Moravec 2013). Besides salmonids, this parasite is sometimes found in other, mostly predatory or occasionally predatory fishes that acquire accidental infections while feeding on the definitive hosts of S. ephemeridarum, i.e. small salmonids. Also in the present case, apparently the eel acquired the $S$. ephemeridarum infection secondarily by occassional preying upon small trouts.

The intermediate hosts of $S$. ephemeridarum are different species of mayflies (Ephemeroptera), whereas some small fishes [Cottus gobio Linnaeus, Barbatula barbatula (Linnaeus)] may serve as paratenic hosts (Moravec 2013).

\section{Spinitectus inermis (Zeder, 1800)}

This nematode was found in one locality belonging to the Elbe River basin: Mácha Lake fishpond system (November 1975: 1/1, 4; September 1976: 1/5, 12; December 1976: 1/5, 1; August 1981: 1/1, 2; August 1994: 6\% [1/16], 1).

Spinitectus inermis is a specific gastrointestinal parasite of the European eel $A$. anguilla. It occurs only locally and is a rather rare parasite of eels in most localities. The intermediate hosts of this nematode are mayflies (Ephemeroptera) (Saraiva et al. 2002). It can be assumed that both infected mayfly intermediate hosts and fish paratenic hosts are the source of infection for eels (Moravec 2013)

\section{Eustrongylides mergorum (Rudolphi, 1809) larv.}

Larvae of this parasite were recorded from the stomach wall of an eel in one locality belonging to the Elbe River basin: Mácha Lake fishpond system (February 1967: 1/1, 2).

The definitive hosts of E. mergorum are different fisheating birds, whereas aquatic oligochaetes apparently serve as intermediate hosts (Karmanova 1968). Larvae of this nematode occur in a variety of fish species serving as paratenic hosts. Larvae of E. mergorum were reported from eels by Moravec (1985) and Køie (1988) in the Czech Republic and Denmark, respectively.

\section{Porrocaecum ensicaudatum (Zeder, 1800) larv.}

Larvae of this species were found in the intestinal lumen of an eel in one locality belonging to the Elbe River drainage system: Úhlavka Rivulet near Strúbro (September 1994: 1/7, 3).

Larvae of $P$. ensicaudatum were previously recorded from the intestine and pyloric caeca of Salmo trutta fario in the Bystrice River near Olomouc (Danube River basin) (Moravec 1971). The definitive hosts of this nematode are various birds mainly of the family Turdidae. It can be supposed that the nematode larvae only shortly survive in fishes after ingestion of their intermediate hosts, earthworms. Apparently, the European eel is a dead-end host in the circulation of this parasite in the environment. 


\section{Acanthocephala}

Acanthocephalus anguillae (Müller, 1780)

This parasite was found only in the Elbe River basin: Kamenice River near Hřensko (November 1977: 3/5, 1-14 [7]); Ploučnice River near Česká Lípa (September 1994: 13\% [3/24], 1-2 [1]); Ohře River near Postoloprty (October 1994: 45\% [14/31], 1-25 [6]); Orlík water reservoir near Štědronín (October 1994: 7\% [1/15], 1; June 1996: 9\% [1/11], 1; October 1996: 7\% [1/15], 1); Sázava River near Chřenovice (August 1995: 23\% [3/13], 2-16 [7]).

This acanthocephalan is reported from many species of freshwater fishes belonging to different families, but its preferred hosts seem to be numerous cyprinids (Moravec 2004). In the Elbe River basin of the Czech Republic, A. anguillae was previously recorded from eels by Srámek (1901) in the Elbe River at Poděbrady and by Volf and Smíšek (1955) in the Sázava and Lužnice Rivers. It has not yet been found in eels of the Danube basin in the Czech Republic (although it was recorded there in other fish hosts) (see Moravec 2001), but Žitňan (1979) listed A. anguillae from eels in the Danube River in Slovakia.

The life cycle of $A$. anguillae involves the intermediate host, Asellus aquaticus Linnaeus (Isopoda), in which the infective larval stage, the cystacanth, develops (Moravec 2004). The source of $A$. anguillae infection for eels may be both isopod intermediate hosts and fish definitive (possibly also paratenic) hosts.

\section{Acanthocephalus lucii (Müller, 1780)}

This acanthocephalan species was recorded from eels in all of the three main river drainage systems.

Elbe River basin: Lužnice River near Lomnice nad Lužnicí (May 1964: 2/2, 1; May 1977: 1/1, 8); Kamenice River near Hřensko (November 1977: 3/5, 1-10 [5]; July 1979: 1/3, 3; June 1991: 1/1, 1;); Mácha Lake fishpond system (January 1967: 1/3, 1; April 1976: 4/8, 1-17 [5]; May 1976: 1/2, 2; June 1976: 1/3, 3; August 1976: 1/1, 5; September 1996: 3/5, 1-2 [2]; October 1996: 1/4, 1; May 1977: 2/3, 4-8 [6]; September 1977: 14\% [2/14], 2-3 [3]; May 1981: 1/2, 3; June 1981: 2/6, 1-2 [2]; December 1981: 1/1, 18; February 1982: 1/3, 2; March 1982: 4/9, 1-5 [3]; April 1982: 3/8, 1; May 1982: 2/5, 1; 50\% [6/12], 1-16 [4]; July 1982: 7/9, 1-13 [4]; August 1982: 3/7, 1-2 [2]; September 1982: 5/8, 1-4 [2]; October 1982: 1/5, 1; May 1987: 35\% [7/20], 1-7 [3]; May 1990: 2/3, 3-35 [19]; August 1994: 13\% [2/16], 1-2 [2]; September 1995: 9\% [2/22], 1; December 2000: 2/3, 3-6 [5]; May 2003: 2/3, 2-8 [5]; June 2003: 1/1, 2); Vltava River near Zbraslav (July 1988: 5/5, 6-27 [15]); Lužnice River near Tábor (May 1994: 20\% [2/10], 1-2 [2]); Orlík water reservoir near Štědronín (June 1994: 2/9, 2-5 [4]; October 1994: 7\% [1/15], 1; June 1997: 14\% [2/14], 1-20 [11]; October 1997: 19\% [3/16], 1-6 [3]); Starý Brook near Kdyně (September 1994: 18\% [4/22], 1; Sázava River near Chřenovice (August 1995: $23 \%$ [3/13], 1-8 [4];

Danube River basin: Fryšták water reservoir near Zlín (September 1994: 10\% [1/10], 1; Mostiště water reservoir on the Oslava River near Velké Meziř́ičí (May 1995: 36\% [9/25], 2-28 [9]);

Oder River basin: Kružberk water reservoir on the Moravice River near Kružberk (June 1996: 6/8, 2-14 [9]).

This acanthocephalan occurs in many species of freshwater fishes, mainly those which are piscivorous or feeding on macrobenthic invertebrates, belonging to different families (see Moravec 2004). Perca fluviatilis seems to be one of the most frequent definitive hosts in Europe (see Moravec 2001). From eels in the Czech Republic, A. lucii was previously reported from all three main river drainage systems: the Oder River basin (Moravice River - Dyk and Lucký 1956), the Danube River basin (Svratka River - Vojtková 1959) and the Elbe River basin (Mácha Lake fishpond system - Moravec 1978, 1985).

The life cycle of $A$. lucii involves an intermediate host, the freshwater isopod Asellus aquaticus (see Moravec 2004). The source of infection for eels may be either infected intermediate host isopods (A. aquaticus) or prey fishes, most frequently small perch ( $P$. fluviatilis) harbouring these parasites.

\section{Echinorhynchus truttae Schrank, 1788}

This species was recorded from eels only in the Elbe River basin: Kamenice River near Hřensko (November 1978: 1/5, 1; July 1979: 1/3, 1).

Adults of $E$. truttae are found mainly in the intestine and pyloric caeca of various salmonids, but also in some fishes belonging to other families. The intermediate hosts of this acanthocephalan are amphipods of the genera Echinogammarus Stebbing, Gammarus, Pontoporeia Kohlm and Pallasea Bate (see Moravec 2013). Cystacanths of E. truttae were also recorded in the Czech Republic: in the summer of 1962, these were commonly found in Gammarus fossarum Koch from the trout brook Vydří potok (Elbe River basin) in the Šumava Mountains (late V. Baruš, Masaryk University, Brno, CR - unpubl. data; J. Groschaft, Institute of Parasitology, Biology Centre, ASCR, České Budějovice, CR - unpubl. data; F. M. - unpubl. data). The source of E. truttae infection for eels are probably both the intermediate hosts (mainly Gammarus spp.) harbouring the cystacanths and infected fish definitive hosts (mainly small trouts) which may become a prey for larger eels.

\section{Neoechinorhynchus rutili (Müller, 1780)}

This species was recorded from localities belonging to two main river drainage systems.

Elbe River basin: Podhora water reservoir on the Teplá River near Teplá (May 1988: 6\% [1/16], 1); Lužnice River near Tábor (May 1994: 10\% [1/10], 1); Úhlavka Rivulet near Stř́bro (September 1994: 1/7, 1); Ohře River near Postoloprty (October 1994: 3\% [1/31], 3); Ještědský Brook near Ralsko (August 2001: 2/6, 1-2 [2]).

Danube River basin: Rokytná River near Vémyslice (May 1986: 1/2, 2).

This acanthocephalan species is a widely distributed Holarctic parasite mainly of various cyprinids, but it frequently occurs in fishes belonging to other families or even orders (Moravec 2004). In the Czech Republic, N. ru- 
tili was reported from eels by Gelnar et al. (1990) in the Rímov water reservoir on the Malše River (Elbe River basin) and by Moravec and Scholz (1991b) in the Rokytná River (Danube River basin).

Like in other congeneric species, the life cycle of $N$. rutili requires an obligate intermediate host, various species of Ostracoda, whereas some other invertebrates (leeches, alder flies, crayfish), in which larvae of this parasite were observed, may apparently serve only as paratenic hosts (Moravec 2004). Probably some fishes serve only as paratenic or postcyclic hosts of $N$. rutili. It can be assumed that eels become infected with this acanthocephalan mainly by feeding on invertebrate and fish paratenic hosts and on fish definitive hosts.

\section{Pomphorhynchus laevis (Müller, 1776)}

This acanthocephalan species was recorded from eels only in the Danube River basin: Rokytná River near Vémyslice (May 1986: 2/2, 5-274 [140]; June 1987: 1/1, 25).

Pomphorhynchus laevis was previously reported from eels of this locality by Moravec and Scholz (1991a,b). Adults of this parasite occur in many fish species of different families, but mainly in cyprinids. The life cycle involves an intermediate host, gammarids of the genera Echinogammarus, Gammarus, Pontogammarus Sowinsky and Corophium Latreille, whereas some small fishes serve as its paratenic hosts (Moravec 2013). Eels may acquire the $P$. laevis infection either by feeding on gammarid intermediate hosts harbouring cystacanths or by preying on smal fishes serving as paratenic or definitive hosts.

\section{Hirudinea}

\section{Piscicola geometra (Linnaeus, 1761)}

This species was occasionally found on eels in Mácha Lake fishpond system (Elbe River basin) examined in 1975-1977 (see Moravec 1985).

This ectoparasite is known to occur on many fish species belonging to different families.

\section{Bivalvia}

\section{Glochidium gen. sp. larv.}

This parasite was recorded only once in the Danube River basin: Mostiště water reservoir on the Oslava River near Velké Meziříčí (May 1995: 6\% [1/18], 1). Previously it ws reported by Frič (1908) from eels of the Elbe River basin in Bohemia (see Table 2).

Glochidia are larval stages of bivalves of the mussel order Unioida Stoliczka occurring as ectoparasites on many species of fishes. Køie (1988) reported glochidia of Anodonta cygnea (Linnaeus, 1758) from eels in Denmark.

\section{Copepoda}

\section{Ergasilus sieboldi Nordmann, 1832}

This gill parasite was found only in localities of the Elbe River drainage system: Mácha Lake fishpond system (oc- casionally recorded from eels in 1975-1977 - Moravec 1985; August 1994: 13\% [2/16], 1;); Orlík water reservoir near Štědronín (June 1994: 2/9, 1-3 [2]; October 1994: 7\% [1/15], 1; September 1995: 44\% [7/16], 1-5 [2]; November 1995: 1/7, 1; May 1996: 7\% [1/14], 1; June 1996: 9\% [1/11], 3; October 1996: 53\% [8/15], 1-5 [2]); Otava River near Štědronín (August 1995: 8\% [1/12], 1).

This ectoparasite occurs on many species of fishes belonging to different families. In eels of the Czech Republic, it was previously reported by Vojtková (1959) from the Svratka River (Danube River basin) and by Moravec (1985) from the Mácha Lake fishpond system (Elbe River basin).

Frič (1873) mentioned the presence of another species, Ergasilus gibbus Nordmann, 1832, a specific parasite of A. anguilla, in eels of the present Czech Republic (Elbe River basin - locality not given). However, E. gibbus is a brackish-water species and, therefore, it is highly probable that, in this case, E. sieboldi was misidentified as E. gibbus.

\section{Branchiura}

\section{Argulus foliaceus (Linnaeus, 1758)}

This temporary ectoparasite was found on eels in two localities belonging to the Elbe basin: Mácha Lake fishpond system (August 1994: 6\% [1/16], 1); Otava River near Štědronín (August 1995: 58\% [7/12], 1-2 [1]). In the former locality, a rare occurrence of $A$. foliaceus on eels was previously reported by Moravec (1985).

In the Czech Republic, $A$. foliaceus occurs on the skin of many fish species of different families (Moravec 2001).

\section{Acariformes}

\section{Hydrozetes sp.}

This ectoparasite was recorded on gills of an eel in the Mácha Lake fishpond system (Elbe River basin) (August 1982: 1/7, 4); this finding was reported by Moravec (1985).

\section{Host categories and specificity of macroparasites of $A$. anguilla recorded in the present study}

Regarding host-specificity, the parasites recorded can be roughly divided into the following groups:

(1) Strictly specific species for which eels (Anguilla spp.) serve as the only definitive hosts (as defined by Odening 1976): the monogeneans Pseudodactylus anguillae and P. bini, the cestodes Bothriocephalus claviceps and Proteocephalus macrocephalus, and the nematodes Paraquimperia tenerrima, Anguillicoloides crassus, Daniconema anguillae and Spinitectus inermis.

(2) Species the adults of which also occur in fishes of other families: the monogeneans Gyrodactylus lucii and Gyrodactylus sp., the cestode Triaenophorus nodulosus, the trematodes Azygia lucii and Crepidostomum metoecus, the nematodes Camallanus lacustris, C. truncatus, Cucullanus truttae, Raphidascaris acus and Salmonema ephemeridarum, the acanthocephalans Acanthocephalus anguillae, A. lucii, Echinorhynchus truttae, Neoechinor- 
hynchus rutili, and Pomphorhynchus laevis, the hirudinean Piscicola geometra, the crustaceans Ergasilus sieboldi and Argulus foliaceus, and the acariform Hydrozetes sp. Since the present knowledge of the biology of most of these parasites is inadequate, the role of eels in their life cycles remains unknown. It can be only assumed that for some of them (Azygia lucii, C. truttae, R. acus, N. rutili, A. anguillae, A. lucii, E. truttae, P. laevis, P. geometra, $E$. sieboldi and $A$. foliaceus) the European eel may serve as a true definitive host, although in many cases infections by these parasites are obtained secondarily, upon feeding on their usual fish definitive hosts. For some other parasites $A$. anguilla probably serves only as a postcyclic host (C. metoecus, C. lacustris, C. truncatus and S. ephemeridarum), a paradefinitive host in which it cannot reproduce (T. nodulosus) or an accidental facultative host (G. lucii, Gyrodactylus sp.).

(3) Parasite larvae with a low degree of host specificity, which may infect fishes of different families or orders serving either as intermediate hosts (D. spathaceum, Glochidium sp.), paratenic hosts (E. mergorum) or accidental facultative hosts (P. ensicaudatum).

A comparison of these groups shows that although a rather large proportion $(26 \%)$ of the parasites was represented by the species specific for Anguilla spp., a great majority of them (74\%) was formed by non-specific species represented by adults (61\%) and larvae (13\%). It is of interest that there is no trematode species among the eight parasites specific to eel (two monogeneans, two cestodes and four nematodes) and that three of them (P. anguillae, $P$. bini and $A$. crassus) represent introduced species.

Table 2 shows that all of the eight parasites specific for Anguilla spp. were found in the Elbe River basin and all of them, except for one species (Spinitectus inermis), were also recorded from the Danube River basin either in this study or by other authors in the Czech Republic and neighbouring countries. In contrast, only one parasite specific for Anguilla spp. (Bothriocephalus claviceps) was recorded in the Oder River basin, which may be associated with the fact that eels rather rarely occur in this drainage river system (Dyk and Lucký 1957). The presence of nonspecific parasites in eels reflects the distribution of these species in other fish hosts. For example, Cucullanus truttae was recorded from eels in the Elbe basin, where it occurs in salmonids, but not from eels in the two other river basins, where C. truttae is absent in salmonids (Moravec 2001).

\section{Parasite communities of $\boldsymbol{A}$. anguilla in different localities}

It is well known that the formation of the parasite fauna of fishes is affected by many external factors; some of them condition the existence of a certain parasite in a given environment, whereas the effects of others are manifested only quantitatively. Consequently, the occurrence of a certain fish parasite in the locality is the result of a synergistic effect of many factors enabling its sometimes complicated developmental cycle to be completed. Therefore, an evaluation of a parasite community in a certain fish host species in a given locality should be based on broad, detailed, long- term observations. However, in this study, the numbers of examined eels from most localities are limited and it is impossible to make a reliable comparison of the parasite communities, both qualitative and quantitative, among all the localities investigated.

Nevertheless, the results obtained indicated marked differences in the numbers of parasite species recorded from eels among some well-sampled localities belonging to the same main drainage system. For example, in the Elbe River basin, the highest number (18) of parasite species was recorded from eels in the Mácha Lake fishpond system, followed by Orlík water reservoir and the Ohře River near Postoloprty (13 species each). Ten species of parasites were found in the Lužnice River near Tábor, seven species in each of the Rivers Ploučnice, Sázava and Otava near Štědrotín, six species in the Ještědský Brook near Ralsko, five species in the Podhora reservoir near Teplá, Teplá River at Karlovy Vary and Úhlavka Rivulet near Stříbro, four species in the Elbe and Kamenice Rivers near Hřensko, Vltava River near Zbraslav and Temelín, Želivka water reservoir and pond Bagr at České Budějovice, three species in the Želivka River, pond Šaloun near Lomnice nad Lužnicí and storage ponds at Třeboň, two species in the Libočanský Brook near Žatec, Starý Brook near Kdyně, Bílka reservoir near Klatovy and pond Pohorka near Lišov, one species each in the Metuje River near Náchod, Lipno water reservoir and pond Komorník near Jindřichův Hradec. No parasites were recorded from eels in seven other localities (both streams and still waters); however, except for the warm-water aquaculture of eels in Tisová, only individual eel specimens were examined from these localities.

However, the species composition of parasites of eels was usually different even if the same or similar numbers of these organisms were recorded from eels in different localities. For example, of the seven parasite species recorded from eels in the Otava River (P. anguillae, P. bini, $P$. macrocephalus, $P$. tenerrima, $A$. crassus, $C$. lacustris and $A$. foliaceus), only three (A. crassus, $P$. tenerrima and $C$. lacustris) were found among the six parasites of eels in the Ještědský Brook, where, in contrast, three species (C. metoecus, C. truttae and N. rutili) occurred, which were absent in the Otava River. It is evident that this difference is partly associated with the fact that eels in the Ještědský Brook share the environment with the brown trout (Salmo trutta fario) (C. metoecus and C. truttae are common parasites of salmonids), whereas no salmonids probably occur in the section of the Otava River studied.

Of interest is the proportion of specific and non-specific parasites of eels in the localities. Whereas specific parasites represented about $30-40 \%$ of all species recorded in the localities such as the Mácha Lake fishpond system $(39 \%)$ or the Orlická water reservoir $(31 \%)$, from where high numbers of eels were examined in different seasons, in most other localities it ranged from 0 to $25 \%$ or from 50 to $100 \%$. Of the specific parasites of eels, the most distributed species was the tapeworm $B$. claviceps recorded from 24 localities belonging to all the three main river basins; widely distributed were also the tapeworm $P$. macrocepha- 
lus and the nematode $P$. tenerrima, recorded from 14 and 15 localities, respectively, which belong to the Elbe and Danube basins. The pathogenic swimbladder nematode A. crassus was recorded from eight localities of the Elbe and Danube basins (see above). On the contrary, the nematode $S$. inermis was found in a single locality (Mácha Lake fishpond system) and the nematode $D$. anguillae only in three localities (Mácha Lake fishpond system and Ohře and Ploučnice Rivers). The composition of non-specific parasites found in eels mostly depended on the character of the locality and other fish species co-inhabiting the environment.

Since no long-term observations in the localities under investigation (except for the Mácha Lake fishpond system - see Moravec 1985) were conducted throughout the year and only small numbers of eels from the majority of localities were examined, any quantitative comparisons, both within a given locality and between different localities, were not considered as they would be misleading.

\section{DISCUSSION}

Metazoan parasites of the European eel Anguilla anguilla have been intensively studied, mainly during recent decades, by researchers in many countries of Europe and some of North Africa (e.g. Køie 1988, Schabuss et al. 1997, 2005, Borgsteede et al. 1999, Di Cave et al. 2001, Kennedy 2001, Kennedy and Moriarty 2002, Kennedy and Fitch 1990, Maíllo et al. 2005, Saraiva et al. 2005, Rolbiecki and Rokicki 2006, Kristmundsson and Helgason 2007, Hermida et al. 2008) and numerous papers were published dealing with these parasites and their communities in freshwater, brackish-water and marine environments inhabited by this catadromous fish host.

According to Borgsteede et al. (1999), at least 64 species of macroparasites were known to occur in eels from 13 European countries at that time, but now this number, within the whole range of $A$. anguilla, may be estimated to be around 100. The number (31) of parasite species recorded from eels in the freshwater localities of the Czech Republic is considerably higher as compared with those recorded in freshwater localities in other countries, where the numbers of species are less than 20 , but usually only about 10 (see e.g. Borgsteede et al 1999 for survey). The highest number (35) of macroparasites of eels was reported from Denmark, but this figure concerns eels from freshwater, brackish-water and marine localities (Køie 1988, Borgsteede et al. 1999).

Since the species composition of the parasite fauna of eels is considerably influenced by the presence of nonspecific parasites co-occurring in fishes of other families in the same localities (see above), the most interesting and important is the distribution of the parasites specific for eels (Anguilla spp.). It has been mentioned above that eight specific species were recorded in this study. An additional specific parasite of the European eel, the nematode Rhabdochona anguillae Spaul, 1927, is known to occur only in the streams of Spain and Portugal (Spaul 1927, Saraiva and Moravec 1998); it is also reported from eels in Bulgaria (Margaritov 1968), but this record should be verified, be- cause other Rhabdochona spp., parasites of other fishes, may be accidentally found in $A$. anguilla serving as a postcyclic host (e.g. R. paski Baylis, 1928 from eels in Egypt - Moravec 1974). Rhabdochona anguillae seems to be restricted in its distribution to southern Europe only. A morphologically very similar species, $R$. keralaensis Moravec, Sheeba et Kumar, 2012, is a specific parasite of Anguilla bengalensis (Gray) in India (Moravec et al. 2012).

Amin et al. (2008) described Acanthocephalus rhinensis Amin, Thielen, Münderle, Taraschewski et Sures, 2008 from $A$. anguilla in the Rhine River, Germany. Even though other hosts of this acanthocephalan remain unknown, because of its rarity in eels from the type locality, Amin et al. (2008) assumed that $A$. anguilla is only an accessory host that may play a marginal role in the circulation of this parasite in the environment. Therefore, $A$. rhinensis cannot be considered as a specific parasite of eels. Moreover, the taxonomy of some species of Acanthocephalus Koelreuther, 1771 and Echinorhynchus Zoega in Müller, 1776 parasitising European freshwater fishes seems to be somewhat confused and, consequently, the validity of $A$. rhinensis needs a verification.

In addition to the above-mentioned specific parasites of European eels in freshwaters, there are specific macroparasites occurring in this fish host in the brackish and marine localities, represented by the monogenean Gyrodactylus anguillae Ergens, 1960, the trematodes Deropristis inflata (Molin, 1859) and Bucephalus anguillae Špakulová, Macko, Berrilli et Dezfuli, 2002, the nematode Goezia anguillae Lèbre et Petter, 1983, the acanthocephalan $\mathrm{Pa}$ ratenuisentis ambiguus Van Cleave, 1921 and the copepod Ergasilus gibbus. It may be that also the nematode Cucullanus egyptae Abdel-Ghaffar, Bashtar, Abdel-Gaber, Morsy, Mehlhorn, Al Quraishy et Mohammed, 2014, recently described from $A$. anguilla from off the coast of the Gulf of Suez (Red Sea, Egypt) (Abdel-Ghaffar et al. 2014) is a specific parasite of eels, but it is poorly described and not clearly distinguished by morphometrical features from its congeners; therefore, it should be considered a species inquirenda.

Taxonomic note: Špakulová et al. (2002) described a new trematode species, Bucephalus anguillae (Bucephalidae) from $A$. anguilla in a brackish-water fish farm on the Italian coast of the Adriatic Sea; later this species was also reported from eels in the coastal lagoons of Tunisia (Abdallah and Maamouri 2002) and in Corsica, France (Filippi et al. 2010). This species is probably identical with Gasterostomum fimbriatum Molin, 1859 (different from G. fimbriatum Siebold, 1848 from Perca sp. and Sander sp., which was synonymised with Bucephalus polymorphus Baer, 1827 by Wagener 1858) from the same host (A. anguilla) in northern Italy (Padova) near the Adriatic coast (Molin 1859).

In contrast to the composition of specific parasites of A. anguilla in freshwaters, the group of specific parasites of this fish in brackish and marine waters includes two trematode species, one acanthocephalan species and one copepod species; no specific trematodes, acanthocephalans or copepods occurred in eels from freshwater localities. Of 
the six specific parasites in brackish and marine localities, one (P. ambiguus) represents a species introduced into Europe from North America (Taraschewski et al. 1987).

The group of non-specific adult parasites of eels is rather variable in different localities and mostly depends on the composition of the local fish fauna, because eels acquire the infection by these parasites while feeding on their fish definitive hosts or infected invertebrate or fish intermediate/ paratenic hosts. This group of parasites is highly variable as to the species composition, which differs considerably from one locality to another and with respect to the characteristics of the environment. In addition to the parasite species recorded from eels in this study, other adult non-specific parasites were found in this host in freshwater localities in other countries, for example the trematodes Bunodera luciopercae (Müller, 1776), Crepidostomum farionis (Müller, 1780), Nicolla gallica (Dollfus, 1941), Phyllodistomum folium (Olfers, 1816) and Sphaerostoma bramae (Müller, 1776), the nematodes Pseudocapillaria tomentosa (Dujardin, 1843) and Philometra cyprinirutili (Creplin, 1825), the acanthocephalan Acanthocephalus clavula (Dujardin, 1845) and many others. In marine and brackish-water environments, this group of non-specific parasites of eels is represented by a large number of trematode species (e.g. species of Derogenes Lühe, 1900, Hemiurus Rudolphi, 1809, Lecithaster Lühe, 1901, Lecithochirium Lühe, 1901, Limnoderetrema Bray, 1987 and Podocotyle Dujardin,1845), some nematodes (e.g. species of Cucullanus Müller, 1777 and Hysterothylacium Ward et Magath, 1917), acanthocephalans [e.g. some Echinorhynchus spp. and Acanthocephaloides incrassatus (Molin, 1858)] and the isopod Gnathia maxillaris (Montagu, 1804), which currently occur in other marine and brackish-water fishes.
Non-specific parasite larvae recorded from eels in the Czech Republic have been represented only by four species (Table 2), but this group of parasites includes others, which were found in eels in freshwaters of other European countries, for example, larval Ligula intestinalis (Linnaeus, 1758) and Diplostomum spp. or the nematode larvae of Contracaecum spp., Cosmocephalus obvelatus (Creplin, 1825), Paracuaria adunca (Creplin, 1846), Spiroxys contortus (Rudolphi, 1819) and Streptocara spp. Adults of all of these species, except for $S$. contortus maturing in turtles, are parasites of fish-eating birds. In the marine and brackish-water environments, this group includes some larval cestodes (Grillotia sp., 'Tetraphyllidea'gen. sp.) and nematodes, such as Anisakis simplex (Rudolphi, 1809), Hysterothylacium spp. or Pseudoterranova decipiens (Krabbe, 1878) (e.g. Outeiral et al. 2002, Moravec 2013), the definitive hosts of which are elasmobranchs, marine fishes and marine mammals.

The parasites of the European eel, their life cycles and ecology still remain insufficiently known and it is highly desirable to pay further attention to this highly interesting group of parasitic organisms.

Acknowledgements. We would like to express our gratitude to many local representatives of the then State Fishery and the Czech Union of Sport Fishery for their permission to sample the eels. Thanks are also due to many technicians of the Institute of Parasitology, CAS, previously in Prague and later in České Budějovice, who assisted during the field work and laboratory examinations of eels. This study was partly supported by the Grant Agency of the Czech Academy of Sciences (grant No. 62210), the Czech Science Foundation (grant No. P505/12/G112) and the Institute of Parasitology, BC CAS (institutional support RVO: 60077344).

\section{REFERENCES}

Abdallah L.G.-B., MaAmouri F. 2002: Cycle évolutif de $B u$ cephalus anguillae Špakulová, Macko, Berrilli \& Dezfuli, 2002 (Digenea, Bucephalidae) parasite de Anguilla anguilla (L.). Syst. Parasitol. 53: 207-217.

Abdel-Ghaffar F., Bashtar A.-R., Abdel-Gaber R., Morsy K., Mehlhorn H., Al Quraishy, Mohammed S. 2014: $C u$ cullanus egyptae sp. nov. (Nematoda, Cucullanidae) infecting the European eel Anguilla anguilla in Egypt. Morphological and molecular phylogenetic studies. Parasitol. Res. 113: 3457-3465.

Amin O.M., Thielen F., Münderlem., Taraschewski H., Sures B. 2008: Description of a new echinorhynchid species (Acanthocephala) from the European eel, Anguilla anguilla, in Germany, with a key to species of Acanthocephalus in Europe. J. Parasitol. 94: 1299-1304.

Baruš V., Halačka K., Prokeš M. 1996: Presence and distribution of the nematode Anguillicola crassus in the European eel in the Morava River drainage basin, Czech Republic. Živočišná výroba 41: 219-224.

Baruš V., Moravec F., Prokeš M. 1999: Anguillicolosis of the European eel (Anguilla anguilla) in the Czech Republic. Czech J. Anim. Sci. 44: 423-431.

Blasco-Costa I., Faltýnková A., Georgieva S., Skirnisson K., Scholz T., Kostadinova A. 2014: Fish pathogens near the Arctic Circle: molecular, morphological and ecological evidence for unexpected diversity of Diplostomum (Digenea: Diplostomidae) in Iceland. Int. J. Parasitol. 44: 703-715.
Borgsteede F.H.M., Haenen O.L.M., De Bree J., Lisitsina O.I. 1999: Parasitic infections of European eel (Anguilla anguilla L.) in the Netherlands. Helminthologia 36: 251-260.

ChubB J.C. 1975: A review of seasonal occurrence and maturation of adult helminths in freshwater fish in the British Isles. Parasitology 71: iii-iv.

Chubb J.C. 1982: Seasonal occurrence of helminths in freshwater fishes. Part IV. Adult Cestoda, Nematoda and Acanthocephala. Adv. Parasitol. 20: 1-292.

Conneely J.J., McCARThy T.K. 1986: Ecological factors influencing the composition of the parasite fauna of the European eel, Anguilla anguilla (L.), in Ireland. J. Fish Biol. 28: 207-219.

Di Cave D., Berrilli F., De Liberato C., Orecchia P., Kennedy C.R. 2001: Helminth communities in eels Anguilla anguilla from Adriatic coastal lagoons in Italy. J. Helminthol. 75: 7-13.

Doby J.M., JARECKA L. 1966: Complément à la connaissance de la morphologie et de la biologie de Proteocephalus macrocephalus (Creplin, 1825), cestode parasite de l'anguille. Ann.Parasitol. Hum. Comp. 41: 429-442.

Dupont F., Gabrion C. 1986: Approche experimentale du role de l'hôte paraténique dans la circulation du parasite Bothriocephalus claviceps Goeze, 1782 (Cestoda: Pseudophyllidea). Ann. Parasitol. Hum. Comp. 61: 423-429.

DYK V. 1964: [Parasites of fishes in the North Moravian waters.] Zprávy Vlast. úst. Olomouc, No. 119, pp. 1-4. (In Czech.) 
DYK V., LUCKÝ Z. 1956: [Parasite fauna of fishes of the Moravice River basin.] Př́rod. sb. Ostrav. kraje 4: 571-580. (In Czech.)

DYK V., LUCKÝ Z. 1957: [Investigations into fish parasites in the Moravice River basin.] Sb. Vys. šk. zem. les. v Brně, A, No. 1, pp. 71-82. (In Czech.)

DyK V., LUCKÝ Z. 1963: [Reservoir hosts of the parasites of carp and other commercial fishes.] Sb. Vys. šk. zem. v Brně, B, 11: 53-69. (In Czech.)

ERGENS R. 1961: [Helminth fauna of fishes of two South Bohemian pond systems. I. Cestoidea - tapeworms.] Čs. parasitol. 8: 137150. (In Czech.)

Ergens R., Lom J. 1970: [Causative Agents of Parasitic Diseases of Fishes.] Academia, Praha, 383 pp. (In Czech.)

Faltýnková A., Georgieva S., Kostadinova A., BlascoCosta M., Scholz T., Skirnisson K. 2014: Diplostomum von Nordmann, 1832 (Digenea: Diplostomidae) in the sub-Arctic: descriptions of the larval stages of six species discovered recently in Iceland. Syst. Parasitol. 89: 195-213.

Filippi J.-J., Quilichini Y., Foata J., Marchand B. 2010: Topography and ultrastructure of the tegument of Bucephalus anguillae (Digenea: Bucephalidae), a parasite of the European eel Anguilla anguilla (Osteichthyes: Anguillidae). J. Parasitol. 96: 1102-1111.

FRIČ A. 1873: [On crustaceans of the Czech Lands.] Arch. př́rod. prosk. Čech, II, Part 4, pp. 189-250. (In Czech.)

FrIČ A. 1908: [Czech Fishes and Their Parasites.] Second Edition. Grégr a syn, Praha, 78 pp. (In Czech.)

Gelnar M., Scholz T., Moravec F. 1990: [Preliminary report on the helminths parasitizing fishes of the Malše River.] In: Kubečka J. (ed.), Ichtyofauna řeky Malše a nádrže Ř́mov. Jihočes. muz. v Č, Budějovicích, přírod. vědy, České Budějovice, pp. 142-149. (In Czech.)

Georgieva S., Soldánová M., Pérez-del-Olmo A., Dangel D.R., Sitko J., Sures B., Kostadinova A. 2013: Molecular prospecting for European Diplostomum (Digenea: Diplostomidae) reveals cryptic diversity. Int. J. Parasitol. 43: 57-72.

Golovin P.P. 1977: [Monogeneans of eel during its culture using heated water.] In: Zoological Institute (ed.), Investigations of Monogenoidea in the USSR. USSR Acad. Sci., Leningrad, pp. 144-150. (In Russian.)

Hermida M., Saraiva A., Cruz C. 2008: Metazoan parasite community of a European eel (Anguilla anguilla) population from an estuary in Portugal. Bull. Eur. Ass. Fish Pathol. 28: 35-40.

JARECKA L. 1959: On the life-cycle of Bothriocephalus claviceps (Goeze, 1782). Acta Parasitol. Polon. 7: 527-532.

JARECKA L. 1963: Complément à la connaissance du cycle évolutif de Bothriocephalus claviceps (Goeze, 1782), cestode de $\mathrm{An}$ guilla anguilla L. Compt. Rend. Séanc. Acad. Sci., Paris 256: 4121-4122.

JARECKA L. 1964: Cycle évolutif à un seul hôte intermédiaire chez Bothriocephalus claviceps (Goeze, 1782), cestode de Anguilla anguilla L. Ann. Parasitol. Hum. Comp. 39: 149-156.

JoHN J. 1877: [Helminths of Czech fishes.] Vesmír 6: 18-21, 54-57, 67-69, 91-94, 116-118. (In Czech.)

Karmanova E.M. 1968: [Dioctophymidea of Animals and Man and the Diseases Caused by Them.] Osnovy nematodologii 20 . Nauka, Moscow, 262 pp. (In Russian.)

KAŽIĆ D.M. 1970: Endohelminths of economically most important fishes in Lake Skadar (Yugoslavia). Thesis, Veterinary Faculty, Sarajevo 1970. (In Serbo-croatian.) (Cited from Chubb 1982.)

KenNeDY C.R. 2001: Metapopulation and community dynamics of helminth parasites of eels Anguilla anguilla in the River Exe system. Parasitology 122: 689-698.

Kennedy C.R., Berrilli F., Di Cave D., De Liberato C., Orecchia P. 1998: Composition and diversity of helminth communities in eels Anguilla anguilla in the River Tiber: long-term changes and comparison with insular Europe. J. Helminthol. 72: 301-306.
Kennedy C.R., Fitch D.J. 1990: Colonization, larval survival and epidemiology of the nematode Anguillicola crassus, parasitic in the eel, Anguilla anguilla, in Britain. J. Fish Biol. 36: 117-131.

Kennedy C.R., Moriarty C. 2002: Long-term stability in the richness and structure of helminth communities in eels, Anguilla anguilla, in Lough Derg, River Shannon, Ireland. J. Helminthol. 76: $315-322$.

Kodedová I., Doležel D., BroučKová M., Jirků M., Hy pša V., Lukeš J., Scholz T. 2000: On the phylogenetic positions of the Caryophyllidea, Pseudophyllidea and Proteocephalidea (Eucestoda) inferred from 18S rRNA. Int. J. Parasitol. 30: 1109-1113.

KoubKová B., Baruš V. 2000: The tubenose goby (Proterorhinus marmoratus: Perciformes) as paratenic host of the nematode $A n$ guillicola crassus (Dracunculoidea). Helminthologia 37: 43-45.

KøIE M. 1988: Parasites in European eel Anguilla anguilla (L.) from Danish freshwater, brackish and marine localities. Ophelia 29: 93-118.

Kristmundsson Á., Helgason S. 2007: Parasite communities of eels Anguilla anguilla in freshwater and marine habitats in Iceland in comparison with other parasite communities of eels in Europe. Folia Parasitol. 54: 141-153.

Lacey S.M, Williams I.C., Carpenter A.C. 1982: A note on the occurrence of the digenetic trematode Sphaerostoma bramae (Müller) in the intestine of the European eel, Anguilla anguilla (L.). J. Fish Biol. 20: 593-596.

LUCKÝ Z. 1953: [The finding of the cestode Eubothrium crassum (Bloch, 1779) [sic] in the intestine of an eel from Třeboň.] Čas. Nár. musea, odd. př́rodov. 123: 63-66. (In Czech.)

Macko J.K., Ryšavý B., Špakulová M., Králová I. 1993: Synopsis of cestodes in Slovakia I. Cestodaria, Cestoidea: Caryophyllidea, Spathebothriidea, Pseudophyllidea, Proteocephalidea. Helminthologia 30: 85-91.

Maíllo P.A., Vich M.A., Salvadó H., Marqués A., Gracia M.P. 2005: Parasites of Anguilla anguilla (L.) from three coastal lagoons of the River Ebro delta (Western Mediterranean). Acta Parasitol. 50: 156-160.

MARGARITOV N. 1968: [On the distribution of Rhabdochona anguillae Spaul, 1927 (Nematoda, Spirurata).] Godishnik Sofiysk. Univ., Biol. Fak., 1965/1966, 60: 103-105. (In Bulgarian.)

Molin R. 1859: Nuovi Myzelmintha raccolti ed esaminati. Sitzungsber. K. Akad. Wissensch., Wien 37: 818-854.

Molnár K., Moravec F. 1994: Third-stage larvae of Daniconema anguillae (Nematoda: Dracunculoidea) in the subcutaneous tissue of eel Anguilla anguilla. Folia Parasitol. 41: 215-219.

MolnáR K., SzéKely C. 1995: Parasitological survey of some important fish species of Lake Balaton. Parasitol. Hung. 28: 63-82.

MoraveC F. 1966: The finding of the nematode Paraquimperia tenerrima (v. Linstow, 1878) from eels Anguilla anguilla (L.) in Czechoslovakia. Folia Parasitol. 13: 182-186.

MoraveC F. 1967: The systematic status of the genus Sterliadochona Skrjabin, 1946 (Nematoda: Rhabdochonidae). Folia Parasitol. 14: 371-376.

Moravec F. 1971: Nematodes of fishes in Czechoslovakia. Acta Sci. Nat. Acad. Sci. Bohemoslov. Brno 5: 1-49.

MoraVeC F. 1974: On some nematodes from Egyptian freshwater fishes. Acta Soc. Zool. Bohemoslov. 38: 32-51.

Moravec F. 1975: Some remarks on the development of Paraquimperia tenerrima (Linstow, 1878) (Nematoda: Quimperiidae). Scr. Fac. Sci. Nat. Univ. Purk. Brun., Biol. 5, 4 (Year 1974): 135-142.

MoRAVEC F. 1978: [A survey of endoparasitic worms found in fishes of the Mácha Lake fishpond system.] Scr. Fac. Sci. Nat. Univ. Purk. Brun., Biol. 2, 8: 77-80. (In Czech.)

MoRAVEC F. 1979a: Redescription of the nematode Spinitectus inermis parasitic in eels, Anguilla anguilla, of Europe. Acta Soc. Zool. Bohemoslov. 43: 35-42.

MORAVEC F. 1979b: Occurrence of the endoparasitic helminths in pike (Esox lucius L.) from the Mácha Lake fishpond system. Acta Soc. Zool. Bohemoslov. 43: 174-193. 
Moravec F. 1980: Biology of Cucullanus truttae (Nematoda) in a trout stream. Folia Parasitol. 27: 217-226.

Moravec F. 1985: Occurrence of endoparasitic helminths in eels (Anguilla anguilla $(\mathrm{L}$.$) ) from the Mácha Lake fishpond system,$ Czechoslovakia. Folia Parasitol. 32: 113-125.

MoraVec F. 1992: Spreading of the nematode Anguillicola crassus (Dracunculoidea) among eel populations in Europe. Folia Parasitol. 39: 247-248.

MoraveC F. 1996: Aquatic invertebrates (snails) as new paratenic hosts of Anguillicola crassus (Nematoda: Dracunculoidea) and the role of paratenic hosts in the life cycle of this parasite. Dis. Aquat. Org. 27: 237-239.

Moravec F. 2001: Checklist of the Metazoan Parasites of Fishes of the Czech Republic and the Slovak Republic. Academia, Prague, $168 \mathrm{pp}$.

MoRAVEC F. 2003: Observations on the metazoan parasites of the Atlantic salmon (Salmo salar) after its reintroduction into the Elbe River basin in the Czech Republic. Folia Parasitol. 50: 298-304.

Moravec F. 2004: Metazoan Parasites of Salmonid Fishes of Europe. Academia, Prague, 510 pp.

Moravec F. 2013: Parasitic Nematodes of Freshwater Fishes of Europe. Second Edition. Academia, Prague, 601 pp.

Moravec F., Di Cave D., Orecchia P., Paggi L. 1993: Studies on the development of Anguillicola crassus Kuwahara, Niimi et Itagaki, 1974 (Nematoda: Dracunculoidea) in the intermediate host. Folia Parasitol. 40: 39-48.

Moravec F., Di Cave D., Orecchia P., Paggi L. 1994: Experimental observations on the development of Anguillicola crassus (Nematoda: Dracunculoidea) in its definitive host, Anguilla anguilla (Pisces). Folia Parasitol. 41: 138-148.

Moravec F., Gelnar M., Ergens R., Scholz T. 1997: Metazoan parasites of fishes from the section of the Vltava River supposed to be affected by the operation of the Temelín nuclear power-station, Czech Republic. Acta Soc. Zool. Bohem. 61: 65-76.

Moravec F., KøIE M. 1987: Daniconema anguillae gen. et sp. n., a new nematode of a new family Daniconematidae fam. n. parasitic in European eels. Folia Parasitol. 34: 335-345.

Moravec F., Scholz T. 1991a: Observations on the biology of Pomphorhynchus laevis (Zoega in Müller, 1776) (Acanthocephala) in the Rokytná River, Czech and Slovak Federative Republic. Helminthologia 28: 23-29.

MoraVec F., SchOlz T. 1991b: Occurrence of endohelmiths in chub, Leuciscus cephalus, of the Rokytná River, Czechoslovakia. Acta Soc. Zool. Bohemoslov. 55: 12-28.

Moravec F., Sheeba S., Kumar A.B. 2012: Rhabdochona (Rhabdochona) keralaensis sp. nov. (Rhabdochonidae) and some other nematodes in the Indian mottled eel Anguilla bengalensis bengalensis from India. Acta Parasitol. 57: 74-82.

Moravec F., ŠKoríková B. 1998: Amphibians and larvae of aquatic insects as new paratenic hosts of Anguillicola crassus (Nematoda: Dracunculoidea), a swimbladder parasite of eels. Dis. Aquat. Org. 34: 217-222.

Neumann W. 1985: Schwimmblasenparasit Anguillicola bei Aalen. Fischer und Teichwirt 11: 322.

Nie P., Kennedy C.R. 1991a: Population biology of Proteocephalus macrocephalus (Creplin) in the European eel, Anguilla anguilla (Linaeus), in two small rivers. J. Fish Biol. 38: 921-927.

Nie P., Kennedy C.R. 1991b: Seasonal population dynamics of Paraquimperia tenerrima (Linstow) (Nematoda) in the European eel, Anguilla anguilla (Linnaeus) in three localities of southwest England. J. Fish Biol. 39: 441-449.

Nie P., Kennedy C.R. 1992: Populations of Bothriocephalus claviceps (Goeze) (Cestoda) in the European eel, Anguilla anguilla (L.), in three localities in southwest England. J. Fish Biol. 41: 521-531.

Odening K. 1976: Conception and terminology of hosts in parasitology. Adv. Parasitol. 14: 1-93.
Outeiral S., Alvarez M.F., Iglesias R., Paniagua E., SanMARTÍN M.L. 2002: Non-digenean parasites of eels from estuaries in North-west Spain. Helminthologia 39: 91-97.

PÁR O. 1980: Tapeworms of the genus Bothriocephalus in our fishes. Veterinářství 30: 178-179. (In Czech.)

Pilecka-Rapacz M., Sobecka E. 2004: Nematodes of the intestine and swim bladder of the European eel Anguilla anguilla (L.) ascending Pomeranian rivers. Wiad. Parazytol. 50: 19-28.

Rolbiecki L., Rokicki J. 2006: Parasite fauna of the eel, Anguilla anguilla (Linnaeus, 1758), from the Polish part of the Vistula Lagoon. Wiad. Parazytol. 52: 115-119.

Saraiva A., Antão A., Cruz C. 2005: Comparative study of parasite communities in European eel Anguilla anguilla from rivers of northern Portugal. Helminthologia 42: 99-106.

Saraiva A.M., Moravec F. 1998: Redescription of Rhabdochona anguillae (Nematoda: Rhabdochonidae), a parasite of eel, Anguilla anguilla, in Europe. Folia Parasitol. 45: 233-238.

Saraiva A.M., Moravec F., Pereira A., Cruz C. 2002: Development of Spinitectus inermis (Nematoda: Cystidicolidae), a parasite of eel, Anguilla anguilla, in Europe. Folia Parasitol. 49: $118-126$.

Schabuss M., Kennedy C.R., Konecny R., Grillitsch B., Schiemer F., Herzig A. 2005: Long-term investigation of the composition and richness of intestinal helminth communities in the stocked population of eel, Anguilla anguilla, in Neusiedler See, Austria. Parasitology 130: 185-194.

Schabuss M., Konecny R., Belpaire C., Schiemer F. 1997: Endoparasitic helminths of the European eel, Anguilla anguil$l a$, from four disconnected meanders from the rivers Leie and Scheldt in western Flanders, Belgium. Folia Parasitol. 44: 12-18.

Scholz T. 1986: Observations on the ecology of five species of intestinal helminths in perch (Perca fluviatilis) from the Mácha Lake fishpond system, Czechoslovakia. Acta Soc. Zool. Bohemoslov. 50: 300-320.

Scholz T. 1987: On the occurrence of endoparasitic helminths in perch (Perca fluviatilis L.) from the Mácha Lake fishpond system, Czechoslovakia. Acta Univ. Carol., Biol. 1985: 301-318.

Scholz T. 1989: Amphilinida and Cestoda, parasites of fish in Czechoslovakia. Acta Sci. Nat. Acad. Sci. Bohemoslov. Brno 23: $1-56$.

Scholz T. 1997: Life-cycle of Bothriocephalus claviceps, a specific parasite of eels. J. Helminthol. 71: 241-248.

Scholz T., Drábek R., Hanzelová V. 1998: Scolex morphology of Proteocephalus tapeworms (Cestoda: Proteocephalidae), parasites of freshwater fish in the Palaearctic Region. Folia Parasitol. 45: 27-43.

Scholz T., Hanzelová V. 1998: Tapeworms of the Genus Proteocephalus Weinland, 1858 (Cestoda: Proteocephalidae), Parasites of Fishes in Europe. Studie AV ČR 2. Academia, Prague, 118 pp.

Scholz T., Kepr T. 1988: The first finding of the tapeworm Proteocephalus macrocephalus (Creplin, 1825) (Cestoda: Proteocephalidae) in Czechoslovakia. Folia Parasitol. 35: 111-112.

Scholz T., Moravec F. 1990: A record of gravid cestodes Bothriocephalus claviceps (Goeze, 1782) from the newts Triturus vulgaris (L.) (Amphibia). Folia Parasitol. 37: 283-284.

Scholz T., Špakulová M., Šnábel V., Králová I., HanZELOVÁ V. 1997: A multidisciplinary approach to the systematics of Proteocephalus macrocephalus (Creplin, 1825) (Cestoda: Proteocephalidae). Syst. Parasitol. 37: 1-12.

Shears J.A., Kennedy C.R. 2005: The life cycle of Paraquimperia tenerrima: a parasite of the European eel Anguilla anguilla. J. Helminthol. 79: 169-176.

Sitko J., Faltýnková A., Scholz T. 2006: Checklist of the Trematodes (Digenea) of Birds of the Czech and Slovak Republics. Academia, Prague, $111 \mathrm{pp}$.

Spaul E.A. 1927: On a new species of the nematode genus Rhabdochona. Ann. Mag. Nat. Hist., Ser. 9, 19: 636-641.

Sures B., Streit B. 2001: Eel parasite diversity and intermediate host abundance in the River Rhine, Germany. Parasitology 123: 185-191. 
ŠKoríková B., Scholz T., Moravec F. 1996: Spreading of introduced monogeneans Pseudodactylogyrus anguillae and P. bini among eel populations in the Czech Republic. Folia Parasitol. 43: 155-156.

Špakulová M., Macko J.K., Berrilli F., Dezfuli B.S. 2002: Description of Bucephalus anguillae n. sp. (Trematoda: Bucephalidae), a parasite of the eel Anguilla anguilla (Anguillidae) from a brackish water lagoon of the Adriatic Sea. J. Parasitol. 88: 382-387.

ŠrámeK A. 1901: Helminthen der an der zoologischen Station in Podiebrad (Böhmen) untersuchten Fischen. Arch. naturwiss. Landes. Böhmen 11: 94-118.

Taraschewski H., Moravec F., Lamath T., Anders K. 1987: Distribution and morphology of two helminths recently introduced into European eels populations: Anguillicola crassus (Nematoda, Dracunculoidea) and Paratenuisentis ambiguus (Acanthocephala, Tenuisentidae). Dis. Aquat. Org. 3: 167-176.

Tenora F., Baruš V., Kráčmar S., Dvořáček J., Srnková J. 1999: Parallel analysis of some heavy metals concentrations in the Anguillicola crassus (Nematoda) and the European eel Anguilla anguilla (Osteichthyes). Helminthologia 36: 79-81.

Törnquist N. 1931: Die Nematodenfamilien Cucullanidae und Camallanidae nebst weiteren Beiträgen zur Kenntnis der Anatomie und Histologie der Nematoden. Göteborg. Kungl. Vet. Vitterh. Samh. Handl., Ser. B, 2: 1-441.

VojteK J. 1961: [Helminth larval stages parasitic in fishes in Czechoslovakia]. Wiad. Parazytol. 7: 810-814. (In Polish.)
Vojtek J. 1974: [Metacercariae from fishes in Czechoslovakia.] Folia Fac. Sci. Nat. Univ. Purk. Brun., Biol. 44, 15: 13-51, 2 tabs. (In Czech.)

VoJTKOví L. 1959: [Contribution to the knowledge of the parasites of fishes of the Rivers Svitava and Svratka.] Spisy Přrírod. fak. univ. J. E. Purkyně v Brně, No. 401, pp. 97-123. (In Czech.)

Volf F., SmíšeK J. 1955: [Eel in Czechoslovakian waters.] Sb. Čs. akad. zem. věd 28: 395-410. (In Czech.)

WAGENER C.R. 1858: Enthelmintica VI. Über Distoma campanula Duj. (Gasterostoma fimbriatum Sieb.) und Monostoma bipartitum Wedl. Arch. Naturg. 24: 250-256.

Willemse J.J. 1967: The host-parasite relation between fresh-water fishes and tapeworms of the genus Proteocephalus. Arch. Neerland. Zool. 17: 2892291.

ŽĎÁRSKÁ Z., NebesÁŘová J. 1999a: Regional ultrastructural differences of the scolex and neck tegument of Proteocephalus macrocephalus (Eucestoda: Proteocephalidae). Folia Parasitol. 46: 279-283.

ŽĎÁRSKÁ Z., Nebesá ŘOvÁ J. 1999b: Distribution and ultrastructure of two types of scolex gland cells in adult Proteocephalus macrocephalus (Cestoda, Proteocephalidae). Parasite 6: 49-56.

ŽITŇAN R. 1979: [Helminths of fishes of the Czechoslovak section of the Danube and their epizootiological importance.] Materialy XXI sesii smeshannoy komissii po primeneniyu soglasheniya o rybolovstve v vodakh Dunaya. Budapest 1979, pp. 148-162. (In Russian.)

Cite this article as: Moravec F., Scholz T. 2015: Macroparasites and their communities of the European eel Anguilla anguilla (Linnaeus) in the Czech Republic. Folia Parasitol. 62: 033. 